\title{
Minimizing Adverse Effects of Pb on Maize Plants by Combined Treatment with Jasmonic, Salicylic Acids and Proline
}

\author{
Mahmoud R. Sofy ${ }^{1, *} *$, Mahmoud F. Seleiman ${ }^{2,3, *} \mathbb{0}$, Bushra A. Alhammad ${ }^{4}$, \\ Basmah M. Alharbi ${ }^{5}$ (D) and Heba I. Mohamed ${ }^{6}$ \\ 1 Botany and Microbiology Department, Faculty of Science, Al-Azhar University, Nasr City 11884, Cairo, Egypt \\ 2 Plant Production Department, College of Food and Agriculture Sciences, King Saud University, \\ P.O. Box 2460, Riyadh 11451, Saudi Arabia \\ 3 Department of Crop Sciences, Faculty of Agriculture, Menoufia University, Shibin El-kom 32514, Egypt \\ 4 Biology Department, College of Science and Humanity Studies, Prince Sattam Bin Abdulaziz University, \\ Al Kharj Box 292, Riyadh 11942, Saudi Arabia; b.alhamad@psau.edu.sa \\ 5 Department of Biology, Faculty of Science, University of Tabuk, Tabuk 71491, Saudi Arabia; \\ b.alharbi@ut.edu.sa \\ 6 Biological and Geological Science Department, Faculty of Education, Ain Shams University, \\ Cairo 11566, Egypt; hebaebrahem@edu.asu.edu.eg \\ * Correspondence: mahmoud_sofy@azhar.edu.eg (M.R.S.); mseleiman@ksu.edu.sa (M.F.S.); \\ Tel.: +966-553-153351 (M.F.S.)
}

Received: 23 April 2020; Accepted: 13 May 2020; Published: 14 May 2020

\begin{abstract}
Lead $(\mathrm{Pb})$ is a toxic heavy metal $(\mathrm{HM})$ that harms plant growth and productivity. Phytohormones, such as jasmonic acid (JA) and salicylic acid (SA), and osmoprotectants, such as proline (Pro), play an important role in the physiological and biochemical processes of plants. We investigated the effect of exogenous applications of JA, SA, Pro, and their combination on Pb-stress tolerance in maize as well as their effect on physiological, biochemical, and yield traits. Pb exposure severely affected maize plants, reducing growth, yield, photosynthetic pigments, and mineral (nitrogen, phosphorus, and potassium) nutrients, as well as enhancing electrolyte leakage (EL), malondialdehyde (MDA) accumulation, osmolytes, and non-enzymatic and enzymatic antioxidants. The application of JA, SA, Pro, and their combination enhanced plant growth and induced pigment biosynthesis, and decreased EL, MDA accumulation, and $\mathrm{Pb}$ concentration. All treatments enhanced Pro and total soluble sugar production, glutathione activity, ascorbic acid, phenol, superoxide dismutase, catalase, peroxidase, and mineral nutrients. JA, SA, and Pro application improved physiological processes directly or indirectly, thereby enhancing the ability of maize plants to overcome oxidative damage caused by $\mathrm{Pb}$ toxicity. The combination of JA, SA, and Pro was the most efficient treatment for maize plant growth and development, eliminating the negative consequences of $\mathrm{Pb}$ stress.
\end{abstract}

Keywords: Zea mays L.; lead; chlorophyll; productivity; antioxidant enzymes; ascorbic acid; elemental analysis

\section{Introduction}

Heavy metals (HMs) are traces in the continental crust. Human activities, industrial waste, melting, mining, and weather processes have resulted in HM pollution of soil and water, and this has become an issue of scientific interest [1-4]. The problem faced by Egypt and other countries is that the majority of industrial areas are close to agricultural land. Additionally, roads and highways carry a considerable number of motor vehicles through the cultivated areas. Lead $(\mathrm{Pb})$ is one of the most toxic $\mathrm{HMs}$, 
causing plant stunting, chlorosis, and the inhibition of growth and germination [5,6]. Once inside the cell, $\mathrm{Pb}$ can alter the cell membrane permeability, cause hormonal imbalances, inhibit various sulfhydryl-containing enzymes, alter the mineral nutrient composition, and disrupt water content to create reactive oxygen species (ROS) [7]. Pb can also affect a significant number of plant species by inducing oxidative stress, disrupting the antioxidant defense system, and overproducing ROS. The stress tolerance of plants to HMs depends on the production of antioxidant enzymes that help to scavenge ROS and on the accumulation of osmoprotectants, such as proline (Pro), soluble sugars, and glycine betaine [8]. The incorporation of trace elements from aerial sources through the leaves can have a significant impact on the contamination of plants, particularly of elements such as $\mathrm{Pb}[9]$. Airborne metal sources include stack or duct emissions from flows of air, gas, or vapor, and fugitive emissions such as dust from storage areas or waste piles. Metals are typically emitted from airborne sources as particulates present in the gas stream. Other metals, including $\mathrm{As}, \mathrm{Cd}$, and $\mathrm{Pb}$, can also volatilize during processing at high temperatures [4].

In recent years, much attention has been paid to the development of strategies to reduce HM toxicity in various crops and farming systems in an effort to meet global demands for food, feed, and fiber $[2,10,11]$. Physicochemical methods used to clean up polluted sites by applying chemicals to change the speciation of the metal and prevent it from being taken up by plants $[12,13]$. However, these chemicals are not cost-effective or efficient [14]. Therefore, the quest for eco-friendly, cost-effective, and reproducible alternatives, such as phytohormones and osmolytes, for the remediation of HM-polluted soils must be prioritized. Phytohormones are the most effective endogenous molecules for modulation of physiological and molecular reactions, and are critically required by the plant for its survival under HM stress. As a rule, a high concentration of HMs in many plant species leads to a reduction in root and shoot biomass, which is usually controlled by phytohormones [15]. Pro is an amino acid that can act as an excellent metal chelator against HM stress [16]. Compatible solutes, such as Pro, are organic compounds with a low molecular weight that are highly soluble, and typically non-toxic to cells when present in high concentrations. These solutes can act as defenses for plants against HM stress by contributing to cellular osmotic changes, ROS detoxification, membrane integrity protection, and enzyme and protein stabilization $[17,18]$.

Jasmonic acid (JA) is a plant growth regulator commonly found in higher plants that possess specific plant growth and developmental functions [19]. It is produced from lipid peroxide by increased lipoxygenase activity [20]. JA and its methyl ester, methyl jasmonate, are molecules formed in plants in response to conditions of biotic and abiotic stress [21,22]. JA can be used in limited amounts for enhancing plant growth, gene expression, osmolytes, antioxidant enzymes, and carotenoids, and it can neutralize the toxic effect of HMs $[23,24]$. Salicylic acid (SA; o-hydroxybenzoic acid) is a phenolic acid that is widely distributed in plants. It is considered a hormone-like substance and plays an essential role in regulating the physiological processes of plants, such as flowering, photosynthesis, seed germination, growth, membrane permeability, and defense against abiotic and biotic stress [25-27]. Due to the abovementioned advantages of chemical inducers, we aimed to investigate their effects as combinations or individuals on stressed maize with $\mathrm{Pb}$.

Maize (Zea mays L.) is one of the world's most important cereal grains due to its improved adaptability to a wide variety of environments [28,29]. It is mainly used as a food source and has become the most efficient food and feed raw material [11,30,31]. Additionally, it can be used for bioenergy production [32-34]. Maize grains have a high nutritional value, and its oil is used for cooking. The global cultivated area for maize was 193.7 Mha in 2018, with a total grain production of 1147.6 Mt, and in Egypt, the cultivated maize area was approximately $0.94 \mathrm{Mha}$, with a total grain production of 7.30 Mt [35]. Maize is a C4 plant that is graded as moderately sensitive to HM stresses. However, its growth and yield can be significantly reduced when cultivated under HM stress $[29,36]$.

The purpose this study was to investigate the role of exogenous applications of JA $\left(1.0 \mathrm{mM} \mathrm{L}^{-1}\right)$, SA $\left(1.0 \mathrm{mM} \mathrm{L}^{-1}\right)$, Pro $\left(7.5 \mathrm{mM} \mathrm{L}^{-1}\right)$, and their combination in antioxidant system regulation, photosynthesis of pigments and solutes, and the production of maize under $\mathrm{Pb}$-stress $\left(7.5 \mathrm{mM} \mathrm{L}^{-1}\right.$; 
$\left.\mathrm{Pb}(\mathrm{CH} 3 \mathrm{COO})_{2}\right)$ at 30 and 70 days following sowing. We hypothesized that phytohormones, such as JA, $\mathrm{SA}, \mathrm{Pro}$, and their combination, could play a vital role in plant tolerance toward $\mathrm{Pb}$ stress by boosting plant growth and yields.

\section{Materials and Methods}

\subsection{Experimental Material and Design}

Two field experiments were conducted at the experimental farm of the Faculty of Sciences, Al-Azhar University, Cairo, Egypt, during the two successive seasons (2017 and 2018). Grains of maize cultivar (Zea mays. cv. Hybrid 306) were obtained from the Agricultural Research Center, Ministry of Agriculture, Giza, Egypt. The grains were sterilized for 2 min in a 1\% sodium hypochlorite solution and washed thoroughly several times with distilled water. Then, they were placed in the open air for $2 \mathrm{~h}$ before soaking for $8 \mathrm{~h}$ in distilled water at room temperature.

Maize grains were sown on May 20, 2017, and May 25, 2018. The plot size was $30 \mathrm{~m}^{2}(5 \times 6 \mathrm{~m})$, with $60 \mathrm{~cm}$ between each row and $20 \mathrm{~cm}$ between each plant. The experimental design was a split-plot randomized complete block design with three replicates. $\mathrm{A} \mathrm{Pb}$ treatment, in the form of $\mathrm{Pb}$ acetate $\left(\mathrm{Pb}\left(\mathrm{CH}_{3} \mathrm{COO}\right)_{2}\right)$ (i.e., with and without $\left.7.5 \mathrm{mM} \mathrm{Pb} \mathrm{L}^{-1}\left(\mathrm{CH}_{3} \mathrm{COO}\right)_{2}\right)$ was applied to the main plots, and the exogenous applications (JA, $1.0 \mathrm{mM} \mathrm{L}^{-1}$; SA, $1.0 \mathrm{mM} \mathrm{L}^{-1}$; Pro, $7.5 \mathrm{mM} \mathrm{L}^{-1}$; their combination; and a control) were applied twice to the subplot. The plants were sprayed with the following treatments (JA, SA, proline and/or their combination) twice. The first dose after 30 days from sowing (DAS), two drops of Tween 80 were applied to each treatment solution before spraying to increase distribution on the leaves. After one day from the spray of JA, SA, proline and/or combination, the plants were sprayed with $\mathrm{Pb}$. Moreover, the second dose of treatments and $\mathrm{Pb}$ was applied at $70 \mathrm{DAS}$. The agricultural practices applied were based on the recommended guidelines for maize cultivation in the region.

Soil samples were collected from the experimental area at a depth of $0-30 \mathrm{~cm}$ to analyze various physical and chemical properties. The soil samples were oven-dried, crushed, and passed through a 2-mm sieve. The proportions of sand, silt, and clay were determined using the hydrometer method [37]. Soil $\mathrm{pH}$ was determined in a saturated soil extract, as described by Thomas [38].

The proportions of sand, silt, and clay in the soil samples were $26.3 \%, 24.8 \%$, and $48.9 \%$, respectively. The physical analysis of soil during the two seasons (2017 and 2018) is presented in Table 1. The pH of the irrigation water was 7.12 and 7.22 and the EC was 0.89 and $0.87 \mathrm{dSm}^{-1}$ in the first and second season, respectively.

Table 1. Physical and chemical soil analysis of the investigated area.

\begin{tabular}{lcc}
\hline Parameter & Season 2017 & Season 2018 \\
\hline $\mathrm{TSS}, \mathrm{ppm}$ & 772 & 782 \\
$\mathrm{pH}$ & 7.9 & 7.6 \\
$\mathrm{EC}\left(\mathrm{dS} \mathrm{cm}^{-1}\right)^{*}$ & 1.75 & 1.78 \\
$\mathrm{Cations}\left(\mathrm{mmolc} \mathrm{L}^{-1}\right)^{*}$ & & \\
$\mathrm{Na}^{+}$ & 2.63 & 2.67 \\
$\mathrm{~K}^{+}$ & 0.62 & 0.65 \\
$\mathrm{Ca}^{++}$ & 2.17 & 2.15 \\
$\mathrm{Mg}^{++}$ & 1.0 & 1.0 \\
$\mathrm{Anion}^{+}\left(\mathrm{mmolc} \mathrm{L}^{-1}\right)^{*}$ & & \\
$\mathrm{Cl}^{-}$ & 4.3 & 4.1 \\
$\mathrm{SO}_{4}{ }^{-2}$ & 0.97 & 0.99 \\
$\mathrm{HCO}_{3}{ }^{-}$ & 1.0 & 1.0 \\
$\mathrm{CO}_{3}{ }^{-}$ & nd & nd \\
Soil texture & & \\
Sand & 26.24 & 26.36 \\
Clay & 49.19 & 48.61 \\
Silt & 24.57 & 25.03 \\
Texture & Clay loamy & Clay loamy \\
\hline \multicolumn{2}{r}{ * Saturated }
\end{tabular}

* Saturated soil paste extract to Gupta [39]. 


\subsection{Measurements}

\subsubsection{Growth and Yield Traits}

Plant and leaf samples were collected to analyze growth and physiological and biochemical traits at 80 DAS. While, $2 \mathrm{~m}^{2}$ was harvested at maturity for the analysis of yield and related traits [plant height $(\mathrm{cm})$, ear length $(\mathrm{cm})$, ear diameter $(\mathrm{mm})$, number of row ear ${ }^{-1}$, number of grains ear $^{-1}$, ear weight (g), 100-grain weight (g), ear yield $\left(\mathrm{kg} \mathrm{ha}^{-1}\right)$ ]. Additionally, ear yield of maize was measured on an oven-dry weight basis $\left(65^{\circ} \mathrm{C}\right.$ for $48 \mathrm{~h}$ ). Sub-samples of grains (approximately $5.0 \mathrm{~g}$ ) were ground to pass via a $0.5 \mathrm{~mm}$ sieve for elemental analyses $(\mathrm{N}, \mathrm{P}, \mathrm{K}, \mathrm{Pb}$; Section 2.2.4).

\subsubsection{Biochemical Measurements}

To estimate photosynthetic pigments, $0.5 \mathrm{~g}$ of fresh leaves were ground with a pestle and mortar in liquid nitrogen $(\mathrm{N})$. The samples were treated with $80 \%$ acetone, and the mixture was centrifuged at $20{ }^{\circ} \mathrm{C}$ for $5 \mathrm{~min}$ at $4500 \times \mathrm{g}$. A spectrophotometer (Model 6305, Jenway, Staffordshire, United Kingdom) was used to measure the filtrate absorbance at wavelengths of 470,652 , and $665 \mathrm{~nm}$ to estimate chlorophyll a, chlorophyll b [40], and carotenoids [41], respectively.

The lipid peroxidation products were measured and quantified in terms of malondialdehyde (MDA), as defined by Heath and Packer [42].Maize plant shoots ( $0.5 \mathrm{~g})$ were homogenized in $2 \mathrm{~mL}$ of $0.1 \%(w / v)$ trichloroacetic acid (TCA), followed by $20 \mathrm{~min}$ of centrifugation at $12,000 \times \mathrm{g}$. The collected supernatant $(1 \mathrm{~mL})$ was combined with an equal volume of $10 \%$ TCA containing $0.5 \%(w / v)$ thiobarbituric acid reactive substances (TBARS), heated for $30 \mathrm{~min}$ at $95^{\circ} \mathrm{C}$, and cooled on ice. The reaction product was then centrifuged for $15 \mathrm{~min}$ at $12,000 \times g$, and the absorbance of the supernatant was measured spectrophotometrically at 532 and $600 \mathrm{~nm}$. The MDA concentration was determined according to its molar extinction coefficient $\left(155 \mathrm{mM}^{-1} \mathrm{~cm}^{-1}\right)$ after subtracting the non-specific absorbance $(600 \mathrm{~nm})$.

The electrolyte leakage (EL) of the leaves was determined according to the method of Sullivan [43]. Leaf disks were placed into tubes containing $10 \mathrm{~mL}$ of boiling deionized water, and the EC was reported (EC1). Then, the tubes were heated in a water bath to $45-55^{\circ} \mathrm{C}$ for $30 \mathrm{~min}$, and the EC was measured (EC2). Thereafter, the sample was boiled again for $10 \mathrm{~min}$ at $100^{\circ} \mathrm{C}$, and the EC (EC3) was measured. EL was calculated as follows:

$$
\text { Electrolyte leakage }(\%)=([\mathrm{EC} 2-\mathrm{EC} 1] / \mathrm{EC} 3) \times 100
$$

The Pro concentration of the dried maize leaves was analyzed using a rapid colorimetric method [44]. Briefly, $500 \mathrm{mg}$ of leaves were extracted in $10 \mathrm{~mL}$ of $3.0 \%(v / v)$ sulphosalicylic acid. The mixture was centrifuged at $10,000 \times g$ for $10 \mathrm{~min}$. Then, $2 \mathrm{~mL}$ of the supernatant was transferred to a test tube, and $2 \mathrm{~mL}$ of freshly prepared acid ninhydrin solution was added. The test tubes were incubated in a water bath at $90{ }^{\circ} \mathrm{C}$ for $30 \mathrm{~min}$. The reaction in each test tube was terminated in an ice bath. Each reaction mixture was extracted with $5 \mathrm{~mL}$ of toluene and vortexed for $15 \mathrm{~s}$ before standing for $20 \mathrm{~min}$ in the dark at room temperature to separate the toluene and aqueous phases. Each upper toluene phase was then carefully collected into a cuvette, and its absorbance was read at $520 \mathrm{~nm}$ using a UV-VIS spectrophotometer. The Pro concentration was determined for each sample using a standard curve based on analytical-grade Pro.

Total soluble sugars were determined, according to Irigoyen et al. [45]. Briefly, $200 \mathrm{mg}$ of dried leaves were homogenized in $5 \mathrm{~mL}$ of $96 \% v / v$ ethanol and then washed with $5 \mathrm{~mL}$ of $70 \% v / v$ ethanol before centrifugation at $3500 \times g$ for $10 \mathrm{~min}$. The samples were stored for a while at $4{ }^{\circ} \mathrm{C}$. Then, $0.1 \mathrm{~mL}$ of the extract was reacted with $3 \mathrm{~mL}$ of freshly prepared anthrone reagent $(150 \mathrm{mg}$ anthrone $+100 \mathrm{~mL}$ of $72 \%(v / v)$ sulfuric acid) by heating for $10 \mathrm{~min}$ in a water bath. After cooling, the absorbance of each sample was recorded at $625 \mathrm{~nm}$ using a spectrophotometer.

To determine the glutathione (GSH) concentration, samples of the dry leaves $(50 \mathrm{mg})$ were placed in a tube with $2 \mathrm{~mL}$ of $2 \%(v / v)$ metaphosphoric acid and centrifuged at $17,000 \times g$ for $10 \mathrm{~min}$. The supernatant $(0.9 \mathrm{~mL})$ was neutralized with $0.6 \mathrm{~mL}$ of $10 \%(w / v)$ sodium citrate. Then, a mixture of 
$700 \mu \mathrm{L}$ of $0.3 \mathrm{mM}$ NADPH, $100 \mu \mathrm{L}$ of $6 \mathrm{mM}$ 5,5'-dithiobis-(2-nitrobenzoic acid), $100 \mu \mathrm{L}$ distilled water, and $100 \mu \mathrm{L}$ of the extract was stabilized at $25^{\circ} \mathrm{C}$ for $3-4 \mathrm{~min}$. GSH reductase $\left(10 \mu \mathrm{L}\right.$ of $\left.50 \mathrm{U} \mathrm{mL}^{-1}\right)$ was added to the extract, and the absorbance was read at $412 \mathrm{~nm}$ using a spectrophotometer to calculate the GSH concentrations from a standard curve, as described by Griffith [46].

The ascorbic acid (AsA) concentration of the maize leaves was analyzed using the method described by Mukherjee and Choudhuri [47]. A sample of fully-expanded leaves $(500 \mathrm{mg})$ was extracted in $10 \mathrm{~mL}$ of $6 \%(w / v)$ TCA and then mixed with $2 \mathrm{~mL}$ of $2 \%(w / v)$ dinitrophenylhydrazine, followed by the addition of one drop of $10 \%(w / v)$ thiourea in $70 \%(v / v)$ ethanol. The mixture was then boiled for $15 \mathrm{~min}$ in a water bath. Next, after cooling the samples to room temperature, $5 \mathrm{~mL}$ of $80 \%(v / v) \mathrm{H}_{2} \mathrm{SO}_{4}$ at $0{ }^{\circ} \mathrm{C}$ was added. The absorbance was determined spectrophotometrically at $530 \mathrm{~nm}$. The AsA concentration was calculated from a standard curve plotted using known AsA concentrations.

The free phenol concentration ( $\mathrm{mg} \cdot \mathrm{g}^{-1}$ of dry leaves) was analyzed using Folin-Ciocalteu reagent and sodium carbonate solution, according to Galicia et al. [48]. We weighed $1 \mathrm{~g}$ of each sample, dried it for $16 \mathrm{~h}$ at $65^{\circ} \mathrm{C}$, and then ground it into an extremely fine powder. Then, a 100-mg aliquot of the powder was transferred into an Eppendorf tube and mixed with $6.5 \mathrm{~mL}$ of $50 \%$ methanol. The samples were vortexed and placed in a thermomixer at $65^{\circ} \mathrm{C}$ at $900 \times g$ for $30 \mathrm{~min}$. The tubes were removed from the thermomixer, cooled at room temperature, and centrifuged at $14,000 \times g$ for $5 \mathrm{~min}$. Then, $1 \mathrm{~mL}$ of the supernatant was carefully transferred into a test tube, to which was added $0.8 \mathrm{~mL}$ of $25 \%$ Folin-Ciocalteu reagent $(10 \mathrm{~g}$ sodium tungstate and $2.5 \mathrm{~g}$ sodium molybdate in $70 \mathrm{~mL}$ of $\left.\mathrm{H}_{2} \mathrm{O}\right), 5 \mathrm{~mL}$ of $85 \%$ phosphoric acid, and $10 \mathrm{~mL}$ of concentrated hydrochloric acid. The sample was refluxed for $10 \mathrm{~h}$, and then $15 \mathrm{~g}$ of lithium sulfate, $5 \mathrm{~mL}$ of water, and one drop of bromine were added. After refluxing for $15 \mathrm{~min}$, the sample was cooled at room temperature and made up to a final volume of $100 \mathrm{~mL}$ with distilled water. Then, $2.5 \mathrm{~mL}$ of $2 \mathrm{~N}$ Folin-Ciocalteu was mixed with $7.5 \mathrm{~mL}$ of deionized water and vortexed. The tubes were incubated at $42{ }^{\circ} \mathrm{C}$ for $9 \mathrm{~min}$, and the absorbance was read at $765 \mathrm{~nm}$ using a spectrophotometer.

\subsubsection{Enzyme Activity}

Maize leaves maize were used to estimate the amount of superoxide dismutase (SOD), peroxidase (POX), and catalase (CAT) enzymes. In this regard, $2 \mathrm{~g}$ of the plant materials were homogenized with $10 \mathrm{~mL}$ of $0.1 \mathrm{M}$ phosphate buffer ( $\mathrm{pH}$ 6.8) and centrifuged at $2{ }^{\circ} \mathrm{C}$ for $20 \mathrm{~min}$ at $20,000 \times g$ in a refrigerated centrifuge. The clear supernatant (containing the enzymes) was removed.

The SOD activity (Enzyme Commission number 1.15.1.1) was determined by measuring the inhibition of the autoxidation of pyrogallol using a method described by Marklund and Marklund [49]. The solution $(10 \mathrm{~mL})$ consisted of $3.6 \mathrm{~mL}$ of distilled water, $0.1 \mathrm{~mL}$ of the enzyme, $5.5 \mathrm{~mL}$ of $50 \mathrm{mM}$ phosphate buffer ( $\mathrm{pH} 7.8$ ), and $0.8 \mathrm{~mL}$ of $3 \mathrm{mM}$ pyrogallol (dissolved in $10 \mathrm{mM} \mathrm{HCl}$ ). The rate of pyrogallol reduction was measured spectrophotometrically at $325 \mathrm{~nm}$ at $25^{\circ} \mathrm{C}$. One unit of enzyme activity was defined as the amount of the enzyme that resulted in 50\% inhibition of the autoxidation rate of pyrogallol at $25^{\circ} \mathrm{C}$.

POX activity (Enzyme Commission number 1.11.1.7) was analyzed using a solution containing $5.8 \mathrm{~mL}$ of $50 \mathrm{mM}$ phosphate buffer (pH 7.0), $0.2 \mathrm{~mL}$ of the enzyme extract, and $2 \mathrm{~mL}$ of $20 \mathrm{mM} \mathrm{H}_{2} \mathrm{O}_{2}$. Following the addition of $2 \mathrm{~mL}$ of $20 \mathrm{mM}$ pyrogallol, the increase in the absorbance as pyrogallol in $60 \mathrm{~s}$ was determined spectrophotometrically at $470 \mathrm{~nm}$ at $25^{\circ} \mathrm{C}$ [50]. One unit of enzyme activity was defined as the amount of the enzyme that catalyzed the conversion of $1 \mu \mathrm{M}$ of $\mathrm{H}_{2} \mathrm{O}_{2}$ per min at $25^{\circ} \mathrm{C}$. The blank sample was prepared using buffer instead of the enzyme extract.

CAT activity (Enzyme Commission number 1.11.1.6) was analyzed using the method of Chen et al. [51]. Briefly, $40 \mu \mathrm{L}$ of the enzyme extract was added to $9.96 \mathrm{~mL}$ of $\mathrm{H}_{2} \mathrm{O}_{2}$ phosphate buffer $(\mathrm{pH} 7.0 ; 0.16 \mathrm{~mL}$ of $30 \% \mathrm{H}_{2} \mathrm{O}_{2}$ in $100 \mathrm{~mL}$ of $50 \mathrm{mM}$ phosphate buffer). CAT activity was determined spectrophotometrically via the rate change of $\mathrm{H}_{2} \mathrm{O}_{2}$ absorbance in $60 \mathrm{~s}$ at $250 \mathrm{~nm}$ at $25^{\circ} \mathrm{C}$. The blank sample was prepared using buffer instead of the enzyme extract. One unit of enzyme activity was defined as the amount of the enzyme that reduced $50 \%$ of the $\mathrm{H}_{2} \mathrm{O}_{2}$ in $60 \mathrm{~s}$ at $25^{\circ} \mathrm{C}$. 


\subsubsection{Macronutrient and $\mathrm{Pb}$ Analysis}

To assess the macronutrients, namely, $\mathrm{N}$, phosphorus $(\mathrm{P})$, and potassium $(\mathrm{K})$. Grains of maize were washed 3 times in deionized water and dried for $48 \mathrm{~h}$ at $65^{\circ} \mathrm{C}$. The dried tissues were weighed and ground into a fine powder prior to wet ashing in solution $\mathrm{HC}^{\circ} \mathrm{O}_{4}: \mathrm{HNO}_{3}$ (4:1 v:v).

The $\mathrm{N}$ concentration was determined using a micro-Kjeldahl apparatus as per Horwitz [52]. The blue color method of Jackson [53] was followed to assess the P concentration by reducing molybdenum to molybdophosphoric acid in sulfuric acid to exclude arsenate. Standard reagents, such as sulfomolybdic acid $\left(\mathrm{H}_{2} \mathrm{MoO}_{7} \mathrm{~S}\right)$, molybdenum blue, diluted $\mathrm{H}_{2} \mathrm{MoO}_{7} \mathrm{~S}$, and $8 \%(w / v) \mathrm{NaHSO}_{3}-\mathrm{H}_{2} \mathrm{SO}_{4}$, were used. The $\mathrm{K}$ concentration of the grains was assessed using a flame photometer, as outlined by Page et al. [54].

Grinded grains (300 mg) were digested in $6 \mathrm{~mL}$ nitric acid $(67 \%)$ and $1 \mathrm{~mL}$ hydrogen peroxide $(30 \%)$. Samples after digestion were filtered, and then were diluted in deionized water to a specific volume. The $\mathrm{HM}$ concentration of $\mathrm{Pb}$ in the maize grains was determined by atomic absorption spectrophotometry, as described by Seleiman et al. [32].

\subsection{Statistical Analysis}

We performed an analysis of variance with a general linear model using SPSS 21.0 software (IBM Corp, Armonk, NY USA) on the data obtained pertaining to the effect of the exogenous applications (JA, SA, Pro, and their combination) and Pb-stress treatments and the effects of their interaction on the growth, biochemical traits, yield, and elemental analysis of maize. The means were compared using Tukey's multiple range test, and $p$-values $\leq 0.05$ were considered significant. The standard error of the mean was calculated for each parameter.

\section{Results}

\subsection{Growth and Yield Traits}

The results obtained (Table 2) showed the retarded growth of Pb-stressed plants, with the shoot height, ear length, ear diameter, number of rows per ear, and number of grains per ear during the two successive seasons (2017 and 2018) showing a significant decrease in Pb-stressed maize. Additionally, the results revealed that, with a few exceptions, foliar application of JA, SA, Pro and their combination improved growth traits of maize grown under stress conditions of $\mathrm{Pb}$ compared to untreated plants. The aforementioned increases were more obvious in maize cultivated under $\mathrm{Pb}$ stress and treated with a foliar application of the combination treatment followed by JA treatment.

Table 2. Effect of different exogenous applications on growth of maize grown under lead stress.

\begin{tabular}{|c|c|c|c|c|c|c|c|c|c|c|c|}
\hline \multirow{2}{*}{$\begin{array}{l}\mathrm{Pb} \\
\text { Treatments }\end{array}$} & \multirow{2}{*}{$\begin{array}{l}\text { Exogenous } \\
\text { Treatments }\end{array}$} & \multicolumn{2}{|c|}{ Plant Height $(\mathrm{cm})$} & \multicolumn{2}{|c|}{ Ear Length (cm) } & \multicolumn{2}{|c|}{ Ear Diameter (mm) } & \multicolumn{2}{|c|}{ Number of Row Ear ${ }^{-1}$} & \multicolumn{2}{|c|}{ No. of Grains Ear ${ }^{-1}$} \\
\hline & & S 1 & S 2 & S 1 & S 2 & S 1 & S 2 & S 1 & S 2 & S 1 & S 2 \\
\hline \multirow{5}{*}{ Zero-Pb } & Control & $229.0 \mathrm{~d}$ & $229.2 \mathrm{e}$ & $18.5 \mathrm{~d}$ & $18.6 \mathrm{~d}$ & $44.0 \mathrm{~d}$ & $44.3 \mathrm{abc}$ & $11.6 \mathrm{abc}$ & $12.3 \mathrm{abc}$ & $444 \mathrm{c}$ & $454 \mathrm{c}$ \\
\hline & JA & $244.7 \mathrm{~b}$ & $245.5 \mathrm{~b}$ & $24.2 \mathrm{~b}$ & $24.4 \mathrm{~b}$ & $46.1 \mathrm{~b}$ & $46.3 \mathrm{a}$ & $13.6 \mathrm{ab}$ & $14.3 \mathrm{a}$ & $493 \mathrm{~b}$ & $496 \mathrm{ab}$ \\
\hline & SA & $237.6 \mathrm{c}$ & $237.8 \mathrm{c}$ & $22.1 \mathrm{c}$ & $22.4 \mathrm{c}$ & $45.6 \mathrm{bc}$ & $48.8 \mathrm{a}$ & $13.0 \mathrm{abc}$ & $13.0 \mathrm{abc}$ & $444 \mathrm{c}$ & $446 \mathrm{c}$ \\
\hline & Pro & $231.5 \mathrm{~d}$ & $231.4 \mathrm{~d}$ & $18.7 \mathrm{~d}$ & $19.1 \mathrm{~d}$ & $44.9 \mathrm{c}$ & $44.9 \mathrm{ab}$ & $13.0 \mathrm{abc}$ & $13.6 \mathrm{ab}$ & $426 \mathrm{~d}$ & $466 \mathrm{bc}$ \\
\hline & Combination & $258.0 \mathrm{a}$ & $248.4 \mathrm{a}$ & $26.2 \mathrm{a}$ & $26.3 \mathrm{a}$ & $47.5 \mathrm{a}$ & $47.6 \mathrm{a}$ & $14.3 \mathrm{a}$ & $14.3 \mathrm{a}$ & $532 \mathrm{a}$ & $534 \mathrm{a}$ \\
\hline \multirow{5}{*}{$\mathrm{Pb}$} & Control & $150.6 \mathrm{~h}$ & $150.8 \mathrm{i}$ & $10.7 \mathrm{~h}$ & $10.9 \mathrm{~h}$ & $33.3 \mathrm{i}$ & $33.4 \mathrm{~d}$ & $10.3 c$ & $9.6 \mathrm{~d}$ & $301 \mathrm{i}$ & $301 \mathrm{f}$ \\
\hline & JA & $200.6 \mathrm{e}$ & $200.9 \mathrm{f}$ & $15.0 \mathrm{f}$ & $15.2 \mathrm{f}$ & $38.3 \mathrm{f}$ & $38.5 \mathrm{bcd}$ & $12.3 \mathrm{abc}$ & $13.0 \mathrm{abc}$ & $350 \mathrm{f}$ & 334 ef \\
\hline & SA & $189.5 \mathrm{f}$ & $189.9 \mathrm{~g}$ & $14.3 \mathrm{f}$ & $14.6 \mathrm{f}$ & $35.4 \mathrm{~g}$ & $35.6 \mathrm{~d}$ & $11.6 \mathrm{abc}$ & $11.6 \mathrm{bcd}$ & $341 \mathrm{~g}$ & $345 \mathrm{e}$ \\
\hline & Pro & $170.7 \mathrm{~g}$ & $170.7 \mathrm{~h}$ & $12.2 \mathrm{~g}$ & $12.5 \mathrm{~g}$ & $34.3 \mathrm{~h}$ & $34.5 \mathrm{~d}$ & $11.0 \mathrm{bc}$ & $11.0 \mathrm{~cd}$ & $321 \mathrm{~h}$ & 331 ef \\
\hline & Combination & $230.0 \mathrm{~d}$ & $216.9 \mathrm{e}$ & $17.4 \mathrm{e}$ & $17.7 \mathrm{e}$ & $40.2 \mathrm{e}$ & $38.1 \mathrm{~cd}$ & $13.6 \mathrm{ab}$ & $13.0 \mathrm{abc}$ & $399 \mathrm{e}$ & $402 \mathrm{~d}$ \\
\hline & 1.87 & 1.24 & 0.20 & 0.17 & 0.17 & 1.35 & 0.56 & 0.52 & 0.88 & 7.90 \\
\hline \multicolumn{2}{|l|}{ Significance } & $* *$ & $* *$ & $* *$ & $* *$ & $* *$ & $* *$ & $* *$ & $* *$ & $* *$ & $* *$ \\
\hline \multicolumn{2}{|l|}{ Lead $(\mathrm{Pb})$} & ** & $* *$ & $* *$ & $* *$ & ** & $* *$ & * & $* *$ & ** & $* *$ \\
\hline \multicolumn{2}{|l|}{ Acids (A) } & $* *$ & $* *$ & $* *$ & $* *$ & ** & * & $* *$ & $* *$ & ** & $* *$ \\
\hline \multicolumn{2}{|c|}{ Interaction $(\mathrm{Pb} \times \mathrm{A})$} & $* *$ & $* *$ & $* *$ & $* *$ & $* *$ & ns & ns & ns & ** & * \\
\hline
\end{tabular}

JA = Jasmonic acid; SA = Salicylic acid; Pro = Proline; column with different letters are significantly differed; S 1 = Season 1; S 2 = Season 2; S.E.M. = Standard error of means; column with different letters (a, b, c, d, e, f, g, h, i) are significantly differed from each other as indicated by Tukey test $(p \leq 0.05)$. ns $=$ not significant; ${ }^{*}=p \leq 0.05$; $* *=p \leq 0.01$. 
Ear weight, ear grain yield, 100-grain weight, and grain yield ha ${ }^{-1}$ were significantly decreased in maize plants cultivated under $\mathrm{Pb}$-stress conditions compared with the non- $\mathrm{Pb}$-stressed maize plants (Table 3). Nevertheless, the exogenous treatments (JA, SA, Pro, and their combination) significantly improved these traits in the $\mathrm{Pb}$-stressed plants compared with the untreated plants (Table 3). Furthermore, the combination application (i.e., JA + SA+ Pro) resulted in the highest yield and related traits compared with each exogenous treatment alone. For instance, the combination treatment application (i.e., JA + SA + Pro) resulted in a significant increment in ear weight by $46.35 \%$ and $37.84 \%$, grain yield by $32.48 \%$ and $33.29 \%$, ear yield by $32.47 \%$ and $33.29 \%$, and 100 -grain weight by $43.48 \%$ and $42.25 \%$ during the 2017 and 2018 seasons, respectively.

Table 3. Effect of different exogenous applications on yield and related traits of maize grown under lead stress condition.

\begin{tabular}{|c|c|c|c|c|c|c|c|}
\hline \multirow{2}{*}{ Lead $(\mathrm{Pb})$} & \multirow{2}{*}{$\begin{array}{l}\text { Exogenous } \\
\text { Treatments }\end{array}$} & \multicolumn{2}{|c|}{ Ear Weight (g) } & \multicolumn{2}{|c|}{ 100-Grain Weight (g) } & \multicolumn{2}{|c|}{ Ear Yield (kg ha $\left.{ }^{-1}\right)$} \\
\hline & & S 1 & S 2 & S 1 & S 2 & S 1 & S 2 \\
\hline \multirow{5}{*}{ Zero- $\mathrm{Pb}$} & Control & $170.0 \mathrm{~d}$ & $172.0 \mathrm{~d}$ & $30.3 c$ & $28.0 \mathrm{bc}$ & $9851 \mathrm{~d}$ & $9886 \mathrm{~d}$ \\
\hline & JA & $189.3 \mathrm{ab}$ & $190.3 \mathrm{~b}$ & $34.0 \mathrm{ab}$ & $34.3 \mathrm{ab}$ & $11,382 \mathrm{~b}$ & $11,660 \mathrm{~b}$ \\
\hline & SA & $184.0 \mathrm{bc}$ & $188.0 \mathrm{bc}$ & $33.3 \mathrm{ab}$ & $33.6 \mathrm{ab}$ & 10,775 c & $10,923 \mathrm{c}$ \\
\hline & Pro & $178.7 \mathrm{c}$ & $182.3 \mathrm{c}$ & $33.0 \mathrm{~b}$ & $33.0 \mathrm{ab}$ & $9851 \mathrm{~d}$ & $9966 \mathrm{~d}$ \\
\hline & Combination & $193.3 \mathrm{a}$ & $198.0 \mathrm{a}$ & $35.3 \mathrm{a}$ & $35.3 \mathrm{a}$ & $12,203 \mathrm{a}$ & $12,544 \mathrm{a}$ \\
\hline \multirow{5}{*}{$\mathrm{Pb}$} & Control & $127.3 \mathrm{~g}$ & $134.0 \mathrm{~g}$ & $20.7 \mathrm{f}$ & $21.3 \mathrm{~d}$ & $6490 \mathrm{i}$ & $6523 \mathrm{~g}$ \\
\hline & JA & $152.3 \mathrm{e}$ & $152.0 \mathrm{e}$ & $28.7 \mathrm{~cd}$ & $29.3 \mathrm{abc}$ & $8316 \mathrm{f}$ & $8377 \mathrm{e}$ \\
\hline & SA & $146.0 \mathrm{f}$ & $145.3 \mathrm{f}$ & $27.7 \mathrm{~d}$ & $28.3 \mathrm{bc}$ & $7414 \mathrm{~g}$ & $7484 \mathrm{f}$ \\
\hline & Pro & $145.0 \mathrm{f}$ & $137.7 \mathrm{~g}$ & $23.7 \mathrm{e}$ & $24.3 \mathrm{~cd}$ & $7095 \mathrm{~h}$ & $7310 \mathrm{f}$ \\
\hline & Combination & $186.3 \mathrm{~b}$ & $184.7 \mathrm{bc}$ & $29.7 \mathrm{~cd}$ & $30.3 \mathrm{abc}$ & 8597 e & 8694 e \\
\hline \multicolumn{2}{|l|}{ S.E.M. } & 1.25 & 1.23 & 0.43 & 1.31 & 56.73 & 80.60 \\
\hline \multicolumn{2}{|l|}{ Significance } & $* *$ & $* *$ & $* *$ & $* *$ & $* *$ & $* *$ \\
\hline \multicolumn{2}{|l|}{ Lead $(\mathrm{Pb})$} & $* *$ & $* *$ & $* *$ & $* *$ & $* *$ & $* *$ \\
\hline \multicolumn{2}{|l|}{ Acids (A) } & $* *$ & $* *$ & $* *$ & $* *$ & $* *$ & $* *$ \\
\hline \multicolumn{2}{|c|}{ Interaction $(\mathrm{Pb} \times \mathrm{A})$} & $* *$ & $* *$ & ** & ns & $* *$ & ** \\
\hline
\end{tabular}

JA = Jasmonic acid; SA = Salicylic acid; Pro = Proline; column with different letters are significantly differed; $\mathrm{S} 1$ = Season 1; S 2 = Season 2; S.E.M. = Standard error of means; column with different letters $(\mathrm{a}, \mathrm{b}, \mathrm{c}, \mathrm{d}, \mathrm{e}, \mathrm{f}, \mathrm{g}, \mathrm{h}, \mathrm{i})$ are significantly differed from each other as indicated by Tukey test $(p \leq 0.05)$. ns $=$ not significant; ${ }^{* *}=p \leq 0.01$.

\subsection{Chlorophyll Content}

The leaves of the Pb-stressed maize plants showed a significant reduction in chlorophyll a, chlorophyll b, and carotenoid content compared with non-Pb-stressed plants in both seasons (Figure 1). Nonetheless, the application of exogenous treatments (JA, SA, Pro, and their combination) significantly improved these traits in both $\mathrm{Pb}$-stressed and non- $\mathrm{Pb}$-stressed plants.

\subsection{Osmolyte Content}

In Pb-stressed plants, the osmolyte content (i.e., Pro and total soluble sugars) was significantly increased in combination with various exogenous treatments compared with untreated plants (Figure 2a,b). The most pronounced increases were observed when the combination of exogenous treatments was applied, followed by the JA treatment. 

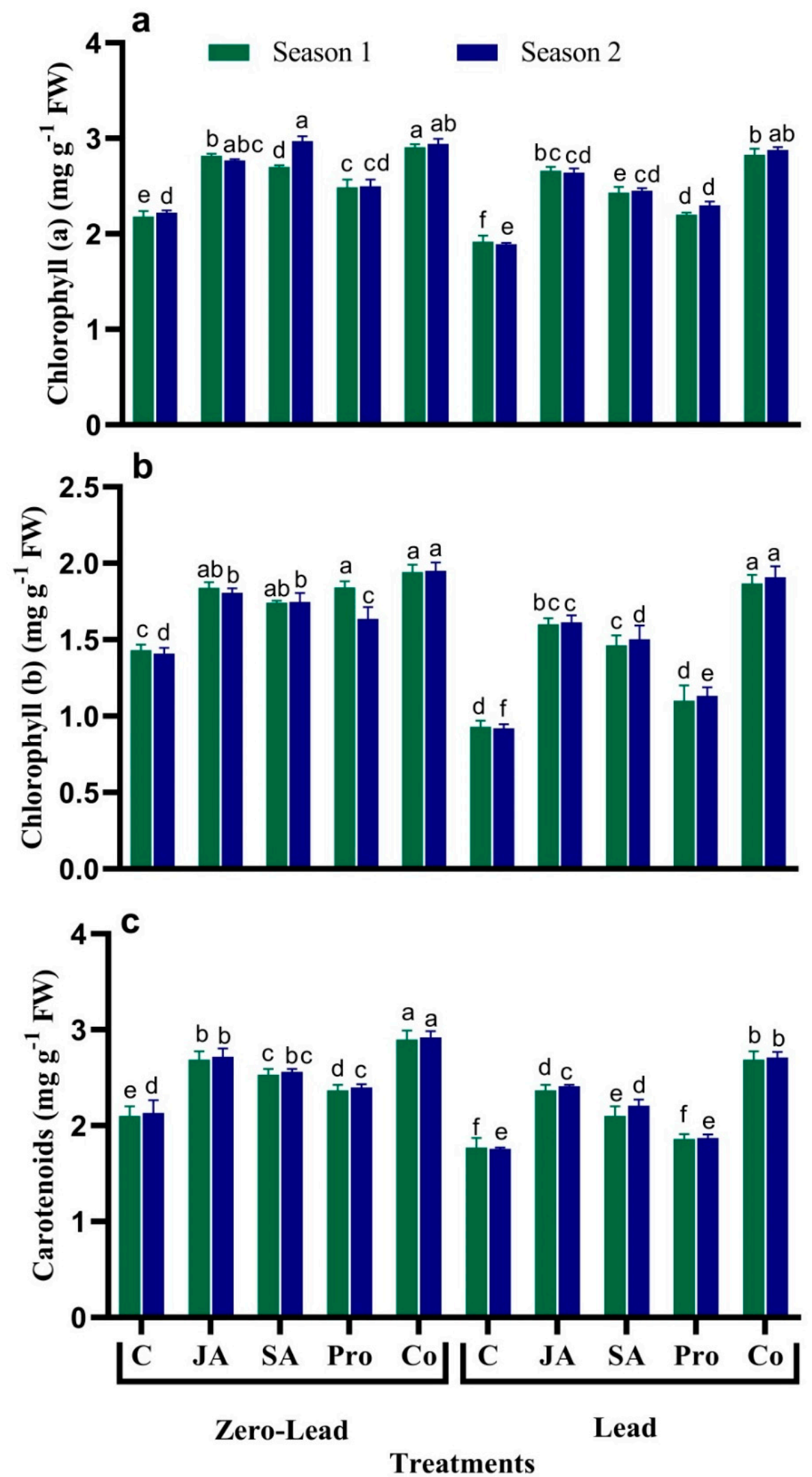

Figure 1. Effect of different exogenous applications on chlorophyll $a, b(\mathbf{a}, \mathbf{b})$ and carotenoids $(\mathbf{c})$ of maize plants grown under lead stress condition. Error bars = Standard error of means (S.E.M.), and bars with different letters $(\mathbf{a}, \mathbf{b}, \mathbf{c}, \mathbf{d}, \mathbf{e}, \mathbf{f})$ are significantly differed from each other as indicated by Tukey test $(p \leq 0.05)$. 


\subsection{Lipid Peroxidation and EL}

TBARS and EL were measured to observe the magnitude of oxidative damage in Pb-stressed maize leaves (Figure 2c,d). The percentage of MDA and EL in the leaves of Pb-stressed plants increased significantly compared with non-Pb-stressed plants. On the other hand, the different exogenous treatments, particularly the combination of JA, SA, and Pro, significantly decreased MDA and EL in Pb-stressed and non- $\mathrm{Pb}$-stressed plants compared with the plants that did not receive exogenous treatments.
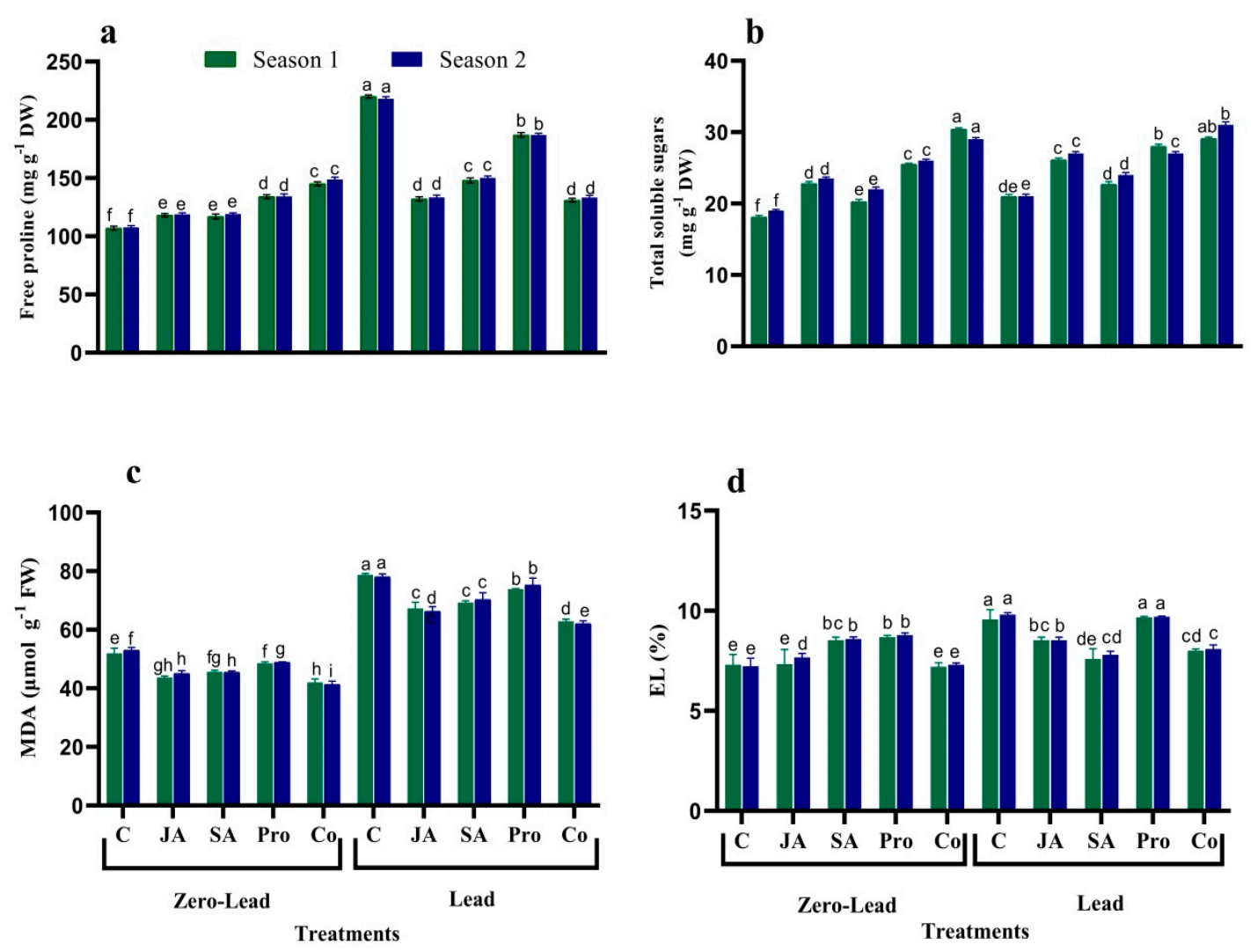

Figure 2. The effect of different exogenous applications on (a) proline, (b) sugars, (c) malondialdehyde (MDA), and (d) electrolyte leakage (EL) of maize plants grown under lead stress condition. Error bars $=$ Standard error of means (S.E.M.), and bars with different letters $(\mathbf{a}, \mathbf{b}, \mathbf{c}, \mathbf{d}, \mathbf{e}, \mathbf{f}, \mathbf{g}, \mathbf{h})$ are significantly differed from each other as indicated by Tukey test $(p \leq 0.05)$.

\subsection{Antioxidant Enzymes}

The activities of SOD, POX, and CAT in the maize plant leaves were significantly increased in $\mathrm{Pb}$-stressed plants compared with non-Pb-stressed plants (Figure 3a-c). Meanwhile, a significant reduction in the activities of SOD, POX, and CAT was noted in Pb-stressed plants as a result of the exogenous treatments (i.e., JA, SA, Pro, and their combination) compared with untreated plants.

\subsection{GSH, AsA, and Phenols}

Hydrophilic antioxidants, like AsA and GSH, are essential components of the antioxidant system that scavenge ROS. We found that $\mathrm{Pb}$-stressed maize plants significantly contained the highest concentration of GSH, AsA, and phenols in their leaves compared with non-Pb-stressed plants (Figure $3 \mathrm{~d}-\mathrm{f}$ ). Conversely, exogenous application of JA, SA, Pro, and their combination significantly reduced GSH, AsA, and phenol concentration in the leaves of maize plants under Pb-stressed conditions compared with untreated plants. The best improvement was observed when the combination treatment was applied to $\mathrm{Pb}$-stressed and non-Pb-stressed plants compared with the other exogenous treatments. 
a

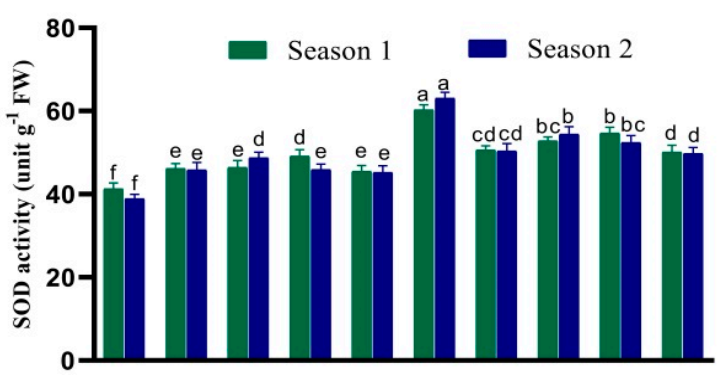

b

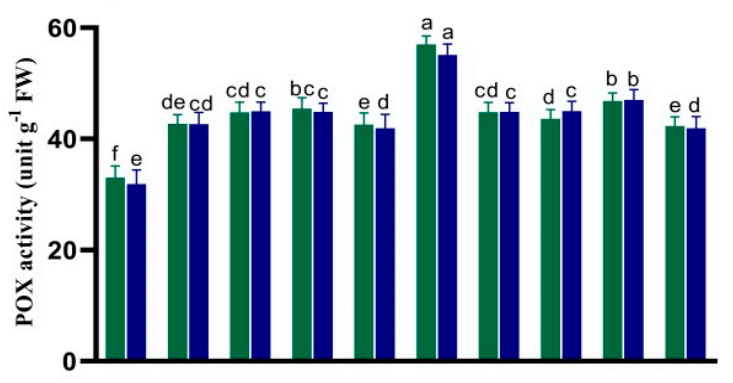

c

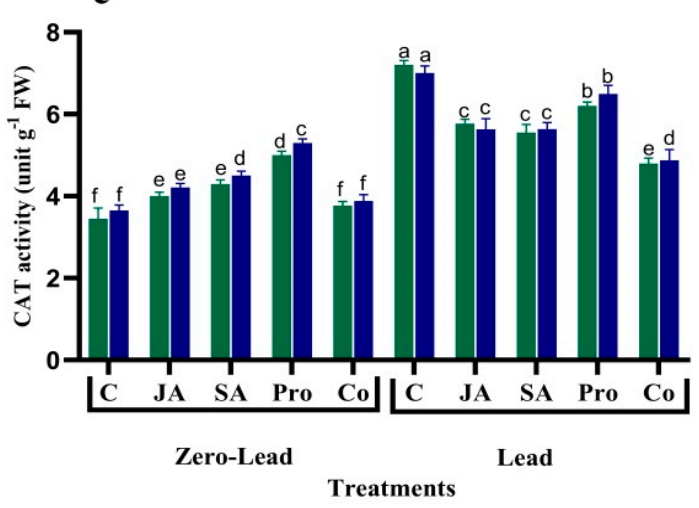

d

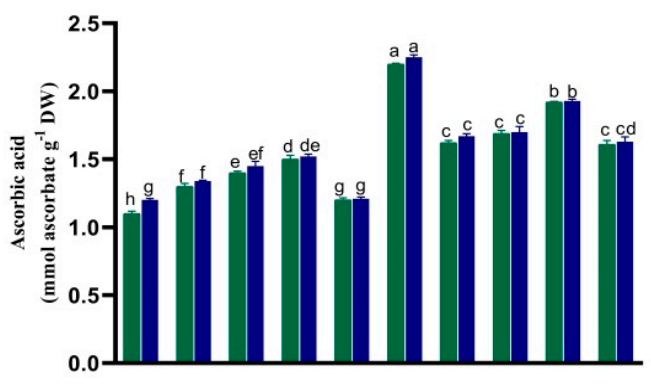

e
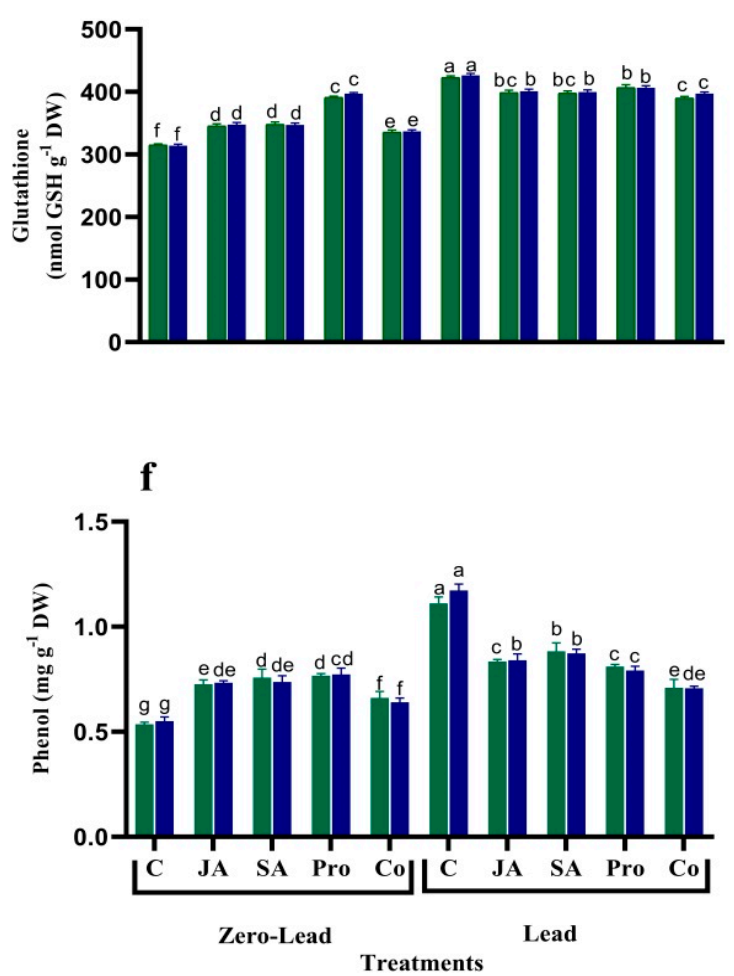

Figure 3. Effect of different exogenous applications on enzyme activity (a,b,c), ascorbic acid (d) glutathione (e), and phenol (f) of maize plants grown under lead stress condition. SOD = superoxide dismutase; $\mathrm{POX}=$ peroxidase; $\mathrm{CAT}=$ catalase. Error bars $=$ Standard error of means (S.E.M.), and bars with different letters $(\mathbf{a}, \mathbf{b}, \mathbf{c}, \mathbf{d}, \mathbf{e}, \mathbf{f}, \mathbf{g}, \mathbf{h})$ are significantly differed from each other as indicated by Tukey test $(p \leq 0.05)$.

\subsection{Macronutrients Concentration and $\mathrm{Pb}$}

$\mathrm{Pb}$ stress caused a significant decrease in the $\mathrm{N}, \mathrm{P}$, and $\mathrm{K}$ concentration of maize grains compared with non-Pb-stressed plants (Figure 4a-c). However, the application of JA, SA, Pro, or their combination significantly increased the $\mathrm{N}, \mathrm{P}$, and $\mathrm{K}$ concentration in maize grains compared with non- $\mathrm{Pb}$-stressed plants (Figure $4 \mathrm{a}-\mathrm{c}$ ). No $\mathrm{Pb}$ was not detected in the grains of non-Pb-stressed maize plants that were treated with any of the exogenous treatments. Furthermore, the application of either JA, SA, Pro, and/or their combination significantly reduced the $\mathrm{Pb}$ concentration in the grains of maize plants treated with $\mathrm{Pb}$ compared with $\mathrm{Pb}$-stressed plants alone (Figure 4d). The most pronounced treatment effect was observed with the combination of exogenous treatments (JA, SA, and Pro). 

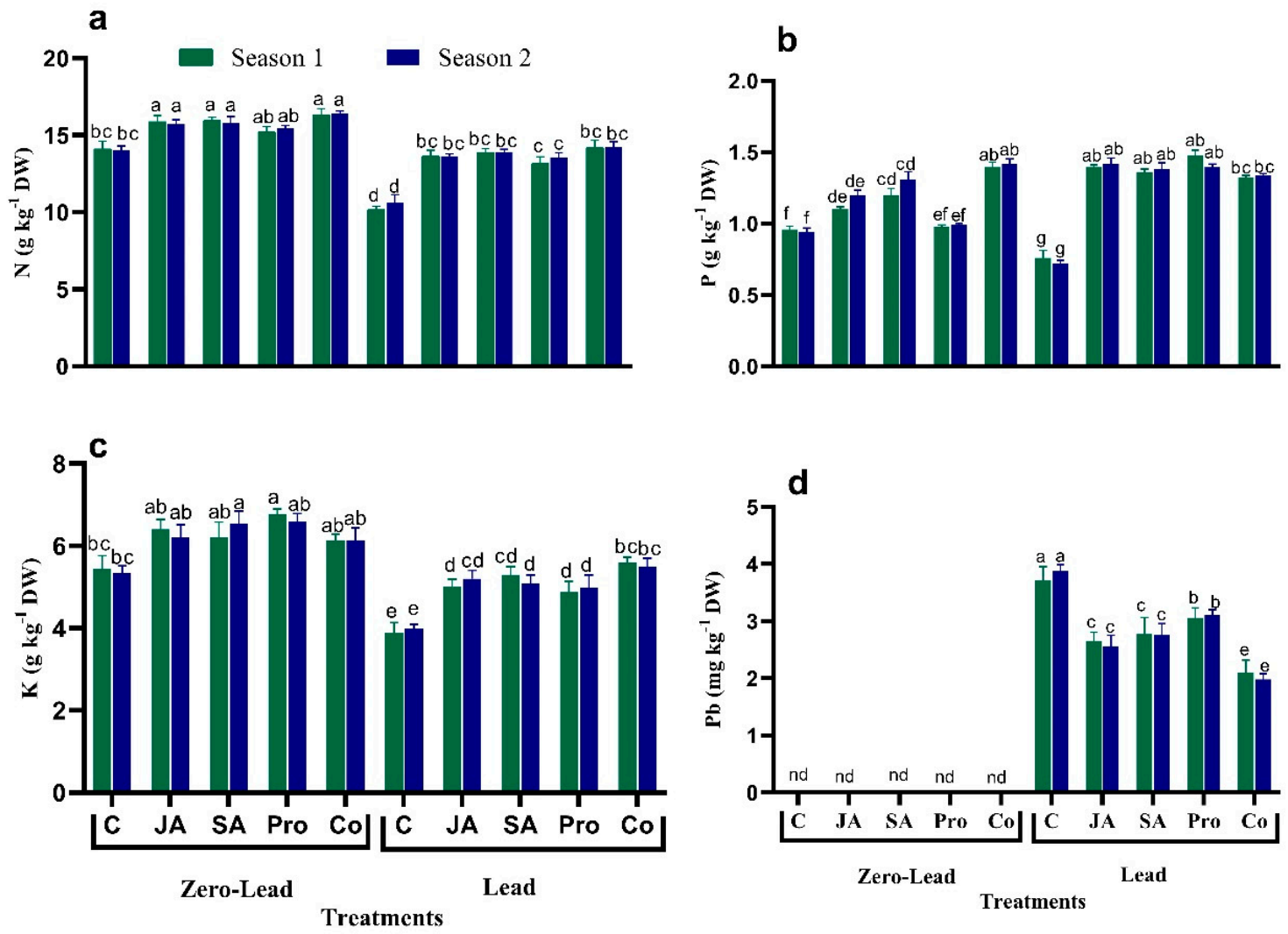

Figure 4. The effect of different exogenous applications on $\mathrm{N}(\mathbf{a}), \mathrm{P}(\mathbf{b}), \mathrm{K}(\mathbf{c}), \mathrm{Pb}(\mathrm{d}$ in grains of maize grown under lead stress condition. Error bars = Standard error of means (S.E.M.), and bars with different letters $(\mathbf{a}, \mathbf{b}, \mathbf{c}, \mathbf{d}, \mathbf{e}, \mathbf{f}, \mathbf{g})$ are significantly different from each other as indicated by Tukey test $(p \leq 0.05)$.

\subsection{Multivariate Statistical Approach}

Hierarchical cluster analysis (HCA) was applied to the different traits from non-Pb-stressed and $\mathrm{Pb}$-stressed plants using nearest-neighbor methods and squared Euclidean distance as a measure of similarity (Figure 5a,b). Generally, two groups were formed by cluster analysis. Cluster 1 included P, POX, PHL, GIU, Pb, CAT, SOD, AS, and PR and comprised two groups, one containing P and the other containing the remainder of the cluster 1 members. Cluster 2 included sugar, NRE, K, N, ED, GE, EY, GY, EL, GM, EW, and PL and comprised two groups, one containing sugar, and the other containing the remainder of the cluster 2 members.

HCA was also applied to the different treatments on the basis of physiochemical parameters and non-Pb-stressed or Pb-stressed conditions (Figure 5d,e). Generally, this resulted in two clusters: cluster 1, comprising the non-stress control, and cluster 2, comprising all the treatments, which were further sub grouped into various clusters, with non-stress combination, non-stress JA, non-stress $\mathrm{SA}$, and non-stress Pro included in the same subgroup. On the other hand, Pb-stressed combination, $\mathrm{Pb}$-stressed JA, Pb-stressed SA, and Pb-stressed Pro were included in the same cluster, which could be attributed to the lower level of physiochemical variations. A principal component analysis was also conducted on the different treatments on the basis of physiochemical parameters and non-Pb-stressed or Pb-stressed conditions. The principle components in season 1 were able to explain $88.73 \%(77.44 \%$ and $10.29 \%$ ) of the total variance. (Figure $5 \mathrm{c}$ ). The principle components in season 2 were able to explain $87.27 \%$ ( $75.90 \%$ and $11.37 \%$ ) of the total variance (Figure $5 f)$. 
Season 1

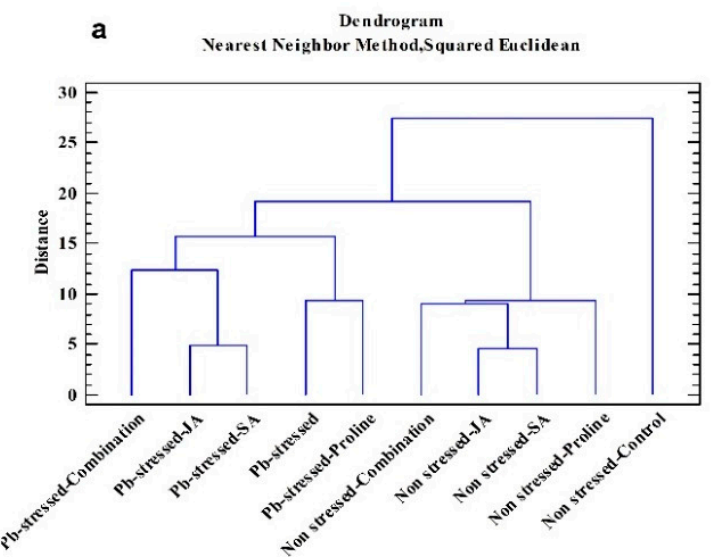

Dendrogram

b Nearest Neighbor Method,Squared Euclidean

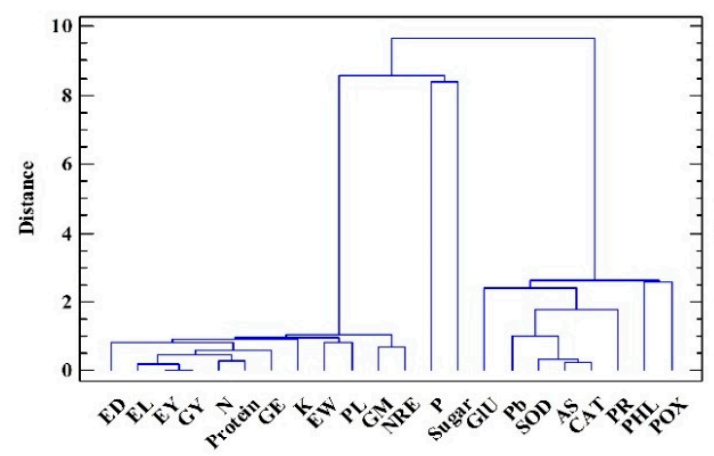

C

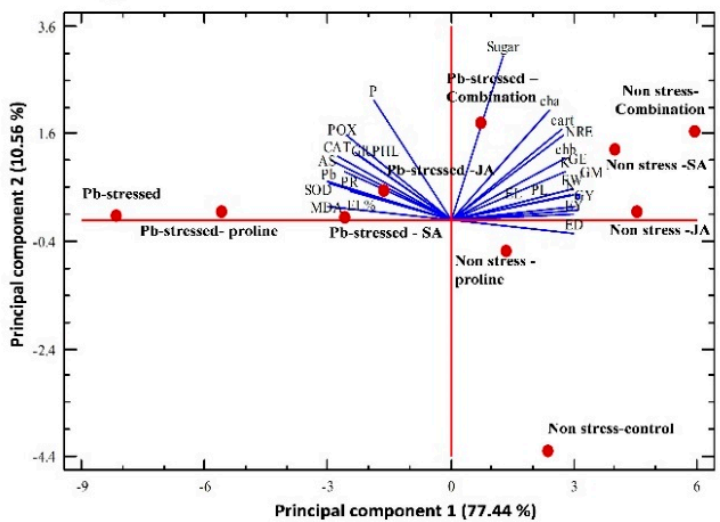

Season 2

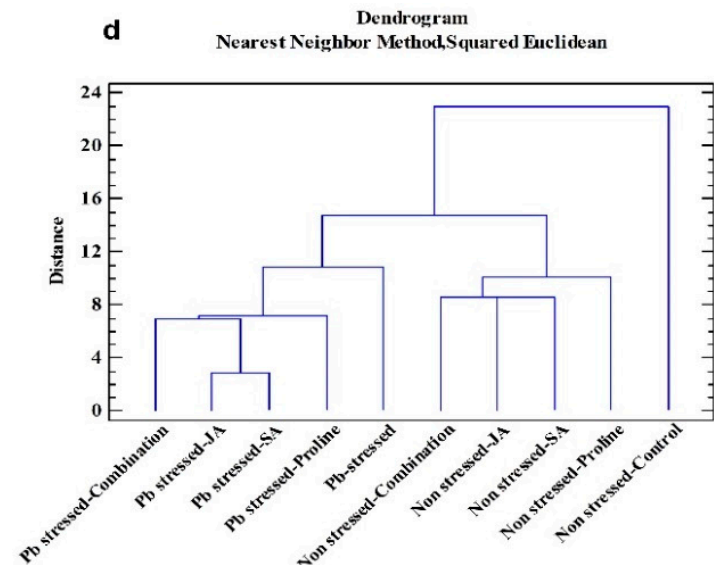

Dendrogram

Nearest Neighbor MethodSquared Euclidean

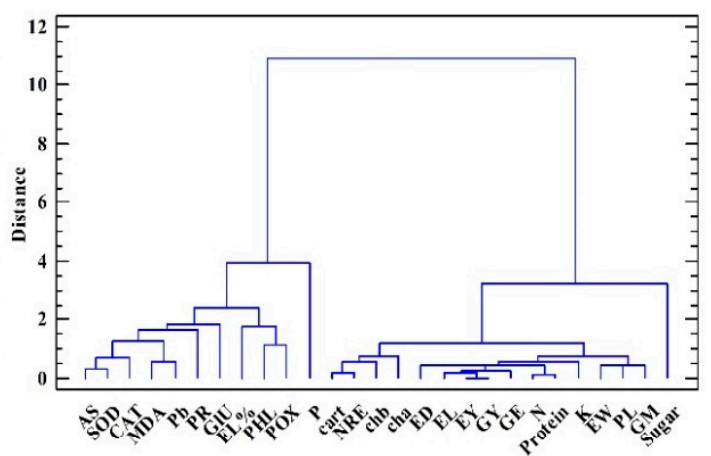

f

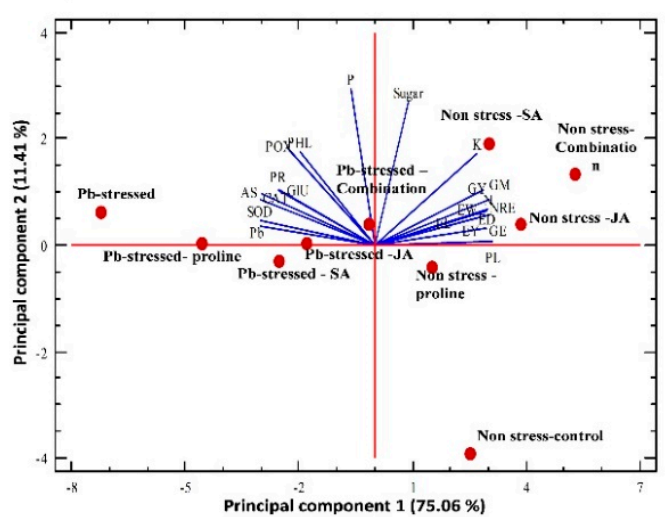

Figure 5. Cluster analysis of plant properties and physiological parameters from the non-stressed, stressed lead conditions of maize plant as shown in $(\mathbf{a}, \mathbf{b}, \mathbf{e}, \mathbf{d})$ and PCA loading plot for different treatment application under non- stressed, stressed lead conditions as shown in $(\mathbf{c}, \mathbf{f})$. PL: plant height $(\mathrm{cm})$, EL: ear length (cm), ED: ear diameter (mm), NRE: no. of rows ear ${ }^{-1}$, GE: no. of grains ear ${ }^{-1}$, EW: ear weight (g), GY: grain yield (g/m²); EY: ear yield/fed (kg) GM: 100 grain mass (g): PR: proline, PHL: phenol, AS: ascorbic acid, GIU: glutathione.

\section{Discussion}

$\mathrm{Pb}$ toxicity negatively impacts plant metabolism thereby inhibiting plant growth and reducing its productivity. The application of $\mathrm{Pb}$ in this experiment significantly reduced the growth and yield traits of $\mathrm{Pb}$-stressed maize plants (Tables 2 and 3). $\mathrm{Pb}$ aligns with the cell wall and the middle lamellae, which enhances the cross-linking of pectins and contributes to cell growth inhibition and, thus, the plant 
as a whole [55]. The application of JA, SA, Pro, and their combination under Pb stress improved growth traits and yield attributes by mitigating the adverse effects of $\mathrm{Pb}$. JA application was found to regulate $\mathrm{Pb}$ uptake and improve carotenoid concentration and growth rates in Wolffia arrhiza under Pb-stress conditions [56]. Furthermore, SA can induce cell division within the apical meristem of seedlings, resulting in the stimulation of plant growth [57]. SA can also be useful in enhancing plant growth or alleviating the toxic effects of $\mathrm{Pb}$ by restoring hydraulic activity and stimulating antioxidant activity [26]. Additionally, the growth of Cicer arietinum plants cultivated under cadmium (Cd) stress was improved in response to Pro application [58]. The improved growth, photosynthetic performance, and antioxidant enzyme activity under the application of exogenous Pro were related to increased yield (Table 3). The improvement in yield may be due to the delayed senescence of plant organs (particularly leaves and flowers) and subsequent avoidance of the premature loss of flowers and fruits. Moreover, SA also promotes cell division and cell enlargement [58]. This increased growth under the influence of exogenous SA is likely to increase the yield traits [59]. Pro can stimulate an increase in the total phenolic concentration of plants [60], and phenolics are known to prevent auxin degradation, which is related to increased seed yield [58]. Furthermore, Hayat and Hayat [61] reported that SA and Pro treatment increased the degree of sink at the seed level, directing the flow of metabolites to the developing seeds, which improved the 100-seed weight and, consequently, the seed yield per plant at harvest in plants under Cd stress.

Photosynthetic pigments are crucial components of photosynthesis and play an essential role in plant growth and the yield of dry matter. In this study, $\mathrm{Pb}$ toxicity in plants resulted in a significant reduction of chlorophyll a, chlorophyll b, and carotenoid concentration in maize plant leaves (Figure 1). Additionally, $\mathrm{Pb}$ exerts a negative effect on photosynthesis by disrupting the ultrastructure of chloroplasts and preventing the synthesis of essential pigments, prevents the Calvin cycle and the electron transport chain, and induces a carbon dioxide shortage by closing the stomatal pores [62]. The reduction in photosynthetic pigments under $\mathrm{Pb}$ stress might be attributable to MDA and EL accumulation (Figure 2). Moreover, photosynthesis inhibition might be due to the interaction of $\mathrm{Pb}$ with the sulfhydryl group in enzymes involved in chlorophyll biosynthesis, thereby impeding the absorption of essential elements, such as iron and manganese, or the substitution of divalent cations with $\mathrm{Pb}$ [63].

However, it was clear from our results that the application of JA, SA, Pro, and their combination improved the accumulation of photosynthetic pigments under both $\mathrm{Pb}$-stress and non- $\mathrm{Pb}$-stress conditions. This may be due to the protective role of JA, which can enhance photosynthesis and the absorption of important minerals under Pb-stress [64]. Additionally, SA plays a role in reducing chlorophyll degradation and the accumulation of MDA and EL in stressed plants [65]. Pro destabilizes the attachment of abscisic acid to specific proteins on the membranes of guard cells, thereby restoring the opening of stomata, resulting in increased stomatal conductivity and photosynthesis [66]. Moreover, Ashraf and Foolad [17] stated that exogenous Pro application could increase the K concentration in the membranes of guard cells, which is important for holding the stomata open, strengthening stomatal conductance, and increasing chlorophyll content. The maize plants in our experiment had a high level of accumulated MDA and EL under Pb-stress treatment (Figure 2), which could result in the breakdown of plant cells. The results of our study confirm the previous findings that $\mathrm{Pb}$ toxicity in plants increases lipid peroxidation and EL [67]. JA protects lipids in the cell membrane by modulating lipid peroxidation during Cd stress. The exogenous application of JA to plants was observed in terms of reduced oxidative stress, as demonstrated by decreased MDA levels [68]. However, Pro and SA treatment inhibited MDA accumulation and EL, which might be due to increased levels of Pro, the accumulation of total soluble sugar, and increased antioxidant enzyme activity, as these inhibit ROS overproduction $[65,66]$.

Plants produce organic solutes that control several physiological processes to cope with abiotic stress. In our experiment, the maize plants under Pb stress showed higher levels of Pro and total soluble sugars compared with non-Pb-stressed plants (Figure 2). The increased accumulation of Pro in plants might be responsible for counteracting $\mathrm{Pb}$-mediated lipid peroxidation and membrane alteration [69]. However, the Pro and total soluble sugar concentration were increased when the plants were treated with JA, SA, Pro, and their combination (Figure 2). The increased accumulation of osmolytes, 
antioxidant enzymes, and carotenoids have been documented to neutralize the toxic effect of metals as a result of JA treatment [24]. Additionally, the exogenous application of SA to plants increased the total soluble concentration of sugar and Pro, which is highly sensitive to various environmental stresses and regulates the multiple genes associated with growth and metabolism, by providing energy resources and carbon [70]. Pro tends to be active in chelating excess cytoplasmic metal ions, which indicates a preference for coordinating $\mathrm{N}$ or oxygen $\left(\mathrm{O}_{2}\right)$ due to its hydrophilic nature. Pro can function as a protein stabilizer, metal chelator, and free radical scavenger to protect enzymes and biomolecules [71].

GSH, AsA, and total phenol concentration were significantly increased in maize leaves under $\mathrm{Pb}$ stress conditions (Figure 3). Some plants may develop their antioxidant defense system to withstand oxidant stress, such as that caused by abiotic stress such as Pb stress or salt stress [72,73]. Furthermore, excessive ROS production can help to disrupt the antioxidant defense mechanism, which is the main effect of $\mathrm{Pb}$ toxicity. Ascorbate and GSH are two essential non-enzymatic components of the redox pool, where AsA prevents the accumulation of toxic $\mathrm{H}_{2} \mathrm{O}_{2}$ by transforming $\mathrm{H}_{2} \mathrm{O}_{2}$ to $\mathrm{H}_{2} \mathrm{O}$ [74]. In the current study, the application of JA, SA, Pro, and/or their combination to maize plants enhanced the total phenol, AsA, and GSH concentration in $\mathrm{Pb}$-stressed plants in comparison with non-Pb-stressed plants (Figure 3). JA may serve as a signaling molecule for the regulation of phytochelatin biosynthesis pathway activities. Additionally, it may reduce the expression of $\mathrm{HM}$ carrier proteins in Arabidopsis thaliana and consequently reduce HM absorption [75]. The increase in GSH and protein-binding thiols may be due to the increased chelation of metal ions that form sulfhydryl compounds [76]. Antioxidants, such as AsA, can also play an important role in metal detoxification [77]. Non-enzymatic (AsA and GSH) and enzymatic (ascorbate peroxidase [APX], CAT, POD) components have been shown to upregulate in Pb-stressed mustard plants in response to the application of SA [78].

The antioxidant system in plants is a well-known defensive mechanism against ROS. In our study, the activity of antioxidant enzymes, such as SOD, CAT, and POX, increased when maize plants were exposed to $\mathrm{Pb}$ stress (Figure 3). The increased activity of these enzymes increased the tolerance of the maize plant to $\mathrm{Pb}$ by modulating the relative quantities of ROS. SOD activity provides a first-line defense system against ROS in coordination with POD and CAT. Pb contamination substantially increased POD activity compared with control plants and was found to be responsible for the detoxification of $\mathrm{H}_{2} \mathrm{O}_{2}$ to $\mathrm{H}_{2} \mathrm{O}$ and $\mathrm{O}_{2}$ [79]. Interestingly, the application of JA, SA, Pro, and their combination further increased the activity of these enzymes under $\mathrm{Pb}$ toxicity in our experiment. JA treatment reduced the negative effect of $\mathrm{Pb}$ stress by inhibiting $\mathrm{Pb}$ aggregation, restoring growth and photosynthetic pigments, and activating enzymes (APX, CAT, and NADH peroxidase) and non-enzymes (GSH and ascorbate) in Wolffia arrhiza plant antioxidants [80]. Further, it was found that the improvement of growth in Cd-stressed plants as a result of SA exogenous application might be because SA acts at the level of transcription and/or translation, thereby increasing the activity of different enzymes that are necessary for plant growth [81]. Additionally, exogenous Pro increased the free Pro content, eliciting its biosynthetic pathways [16] and the activity of the antioxidative enzymes CAT, POX, and SOD by acting at the level of transcription and/or translation.

$\mathrm{Pb}$ stress significantly reduced the concentration $\mathrm{N}, \mathrm{P}$, and $\mathrm{K}$, but it significantly increased the $\mathrm{Pb}$ concentration in maize grains compared with non- $\mathrm{Pb}$-stressed plants (Figure 4). The exogenous application of JA, SA, Pro, and/or their combination significantly increased N, P, and K concentration and decreased $\mathrm{Pb}$ concentration in grains of $\mathrm{Pb}$-stressed maize plants (Figure 4). $\mathrm{Pb}$ was not detected in the grains of non-Pb-stressed plants in the presence of JA, SA, Pro, and their combination or in untreated plants. This was because the roots were the first organs to encounter the toxicity of the $\mathrm{Pb}$ ions [82]. $\mathrm{Pb}$ is retained in the roots due to the binding of $\mathrm{Pb}$ ions to ion-exchange sites located on the cell wall and due to extracellular precipitation. The accumulation of $\mathrm{Pb}$ in roots occurs via binding with polysaccharides and with organic acids and cell walls in the roots and xylem vessels. Thus, $\mathrm{Pb}$ may become immobile in the roots [83].

Pretreatment with JA, SA, Pro, and/or their combination limited the transport and mobility of $\mathrm{Pb}$ from the maize roots to the grains (Figure 4). JA could serve as a signaling molecule to control the 
function of the phytochelatin biosynthetic pathway, or it could reduce the expression of HM conveyor proteins that can minimize metal absorption in plants [64]. It was further noted that SA tends to increase the SA biosynthesis to prevent plant detection by limiting the absorption and accumulation of HMs in plant roots [81]. The increase in SA biosynthesis can increase the production of Pro, which appears to act as a metal chelator of HMs in the cytoplasm. Chelation is essential for the detoxification of HMs, and SA reduces the concentration of HM ions in the cytoplasm by preventing its transport across the plasma membrane [84]. Furthermore, Ali et al. [85] and El-Beltagi et al. [86] demonstrated that Pro alleviated water stress in maize and chickpea plants by promoting the absorption and accumulation of essential nutrients, such as $\mathrm{N}, \mathrm{P}$, and $\mathrm{K}$, indicating that Pro could regulate the absorption of mineral nutrients in stressed plants.

\section{Conclusions}

The treatment of maize plants with JA, SA, Pro, and their combination significantly minimized the negative effects of $\mathrm{Pb}$ on growth and on biochemical and yield traits. The relief provided by JA SA, and Pro to plants under $\mathrm{Pb}$ stress might be due to the inhibition/minimizing of $\mathrm{Pb}$ accumulation in maize plants, thereby decreasing the damage intensity to the membrane system by ROS produced during oxidative stresses. Moreover, JA, SA, Pro, and their combination increased the uptake of essential nutrients, such as N, P, and K, that are required for plant growth. Therefore, JA, SA, Pro, and their combination enhanced photosynthesis-related activity. Furthermore, JA, SA, Pro, and their combination modulated the activity of stress enzymes to ensure maximum protection for maize plants against $\mathrm{Pb}$ stress. Moreover, this study may clarify the possible mechanisms involved in JA-, SA-, and Pro-induced tolerance in maize against $\mathrm{Pb}$ toxicity. Our results showed that the combination of JA, $\mathrm{SA}$, and Pro was the most efficient treatment, followed by JA, to minimize the adverse effects of $\mathrm{Pb}$ and enhance growth and physiological, biochemical, and yield characteristics as well as the concentration of $\mathrm{N}, \mathrm{P}$, and $\mathrm{K}$.

Author Contributions: Conceptualization: M.R.S., M.F.S., B.A.A., B.M.A., and H.I.M.; data curation: M.R.S. and H.I.M.; formal analysis: M.R.S., M.F.S., B.A.A., B.M.A., and H.I.M.; investigation: M.F.S. and B.M.A.; methodology: M.R.S. and H.I.M.; resources: M.R.S. and H.I.M.; software: M.F.S., B.A.A., M.R.S and B.M.A.; writing—original draft: M.R.S., M.F.S., B.A.A., B.M.A., and H.I.M.; writing—review and editing: M.R.S., M.F.S., B.A.A., B.M.A., and H.I.M. All authors have read and agreed to the published version of the manuscript.

Funding: This research received no external funding.

Acknowledgments: The authors thank the Deanship of Scientific Research and RSSU at King Saud University for language editing and plagiarism check support.

Conflicts of Interest: The authors declare no conflict of interest.

\section{References}

1. Ashraf, M.Y.; Roohi, M.; Iqbal, Z.; Ashraf, M.; Öztürk, M.; Gücel, S. Cadmium (Cd) and lead (Pb) induced changes in growth, some biochemical attributes, and mineral accumulation in two cultivars of mung bean [Vigna radiata (L.) Wilczek]. Commun. Soil Sci. Plant Anal. 2016, 47, 405-413.

2. Saleem, M.H.; Ali, S.; Seleiman, M.F.; Rizwan, M.; Rehman, M.; Aisha Akram, N.; Liu, L.; Alotaibi, M.; Al-Ashkar, I.; Mubushar, M. Assessing the Correlations between Different Traits in Copper-Sensitive and Copper-Resistant Varieties of Jute (Corchorus capsularis L.). Plants (Basel) 2019, 8, 545. [CrossRef] [PubMed]

3. Seleiman, M.F.; Ali, S.; Refay, Y.; Rizwan, M.; Alhammad, B.A.; El-Hendawy, S.E. Chromium resistant microbes and melatonin reduced $\mathrm{Cr}$ uptake and toxicity, improved physio-biochemical traits and yield of wheat in contaminated soil. Chemosphere 2020, 126239. [CrossRef] [PubMed]

4. Seleiman, M.F.; Santanen, A.; Mäkelä, P.S. Recycling sludge on cropland as fertilizer-Advantages and risks. Resour. Conserv. Recycl. 2020, 155, 104647. [CrossRef]

5. Mohamed, H.I. Molecular and biochemical studies on the effect of gamma rays on lead toxicity in cowpea (Vigna sinensis) plants. Biol. Trace Elem. Res. 2011, 144, 1205-1218. [CrossRef] 
6. Malar, S.; Vikram, S.S.; Favas, P.J.; Perumal, V. Lead heavy metal toxicity induced changes on growth and antioxidative enzymes level in water hyacinths [Eichhornia crassipes (Mart.)]. Bot. Stud. 2014, 55, 54. [CrossRef]

7. Sharma, P.; Dubey, R.S. Lead toxicity in plants. Braz. J. Plant Physiol. 2005, 17, 35-52. [CrossRef]

8. Siddiqui, M.H.; Al-Whaibi, M.H.; Sakran, A.M.; Basalah, M.O.; Ali, H.M. Effect of calcium and potassium on antioxidant system of Vicia faba L. under cadmium stress. J. Int. J. Mol. Sci. 2012, 13, 6604-6619. [CrossRef]

9. Sharaf, A.; Farghal, I.I.; Sofy, M.R. Role of gibberellic acid in abolishing the detrimental effects of $\mathrm{Cd}$ and $\mathrm{Pb}$ on broad bean and lupin plants. Res. J. Agric. Biol. Sci. 2009, 5, 668-673.

10. El-Beltagi, H.S.; Mohamed, H.I. Alleviation of cadmium toxicity in Pisum sativum L. seedlings by calcium chloride. Not. Bot. Horti Agrobot. Cluj. Napoca 2013, 41, 157-168. [CrossRef]

11. Seleiman, M.F.; Selim, S.; Jaakkola, S.; Mäkelä, P.S. Chemical composition and in vitro digestibility of whole-crop maize fertilized with synthetic fertilizer or digestate and harvested at two maturity stages in Boreal growing conditions. Agric. Food Sci. 2017, 26, 47-55. [CrossRef]

12. Akladious, S.A.; Mohamed, H.I. Physiological role of exogenous nitric oxide in improving performance, yield and some biochemical aspects of sunflower plant under zinc stress. Acta Biol. Hung. 2017, 68, 101-114. [CrossRef] [PubMed]

13. Salem, H.M.; Abdel-Salam, A.; Abdel-Salam, M.A.; Seleiman, M.F. Phytoremediation of metal and metalloids from contaminated soil. In Plants Under Metal and Metalloid Stress; Springer Nature Singapore Pte Ltd.: Singapore, 2018; pp. 249-262.

14. Mohamed, H.I.; Latif, H.H.; Hanafy, R.S. Influence of nitric oxide application on some biochemical aspects, endogenous hormones, minerals and phenolic compounds of Vicia faba plant grown under arsenic stress. Gesunde Pflanzen 2016, 68, 99-107. [CrossRef]

15. Fahad, S.; Hussain, S.; Bano, A.; Saud, S.; Hassan, S.; Shan, D.; Khan, F.A.; Khan, F.; Chen, Y.; Wu, C. Potential role of phytohormones and plant growth-promoting rhizobacteria in abiotic stresses: Consequences for changing environment. Environ. Sci. Pollut. Res. Int. 2015, 22, 4907-4921. [CrossRef] [PubMed]

16. Hayat, S.; Hayat, Q.; Alyemeni, M.N.; Wani, A.S.; Pichtel, J.; Ahmad, A. Role of proline under changing environments: A review. Plant. Signal. Behav. 2012, 7, 1456-1466. [CrossRef] [PubMed]

17. Ashraf, M.; Foolad, M.R. Roles of glycine betaine and proline in improving plant abiotic stress resistance. Environ. Exp. Bot. 2007, 59, 206-216. [CrossRef]

18. Aslam, M.; Saeed, M.S.; Sattar, S.; Sajad, S.; Sajjad, M.; Adnan, M.; Iqbal, M.; Sharif, M.T. Specific role of proline against heavy metals toxicity in plants. Int. J. Pure Appl. Biosci. 2017, 5, 27-34. [CrossRef]

19. Wasternack, C. Action of jasmonates in plant stress responses and development-Applied aspects. Biotechnol. Adv. 2014, 32, 31-39. [CrossRef]

20. Maksymiec, W.; Krupa, Z. Jasmonic acid and heavy metals in Arabidopsis plants-a similar physiological response to both stressors? J. Plant Physiol. 2002, 159, 509-515. [CrossRef]

21. Mohamed, H.I.; Latif, H.H. Improvement of drought tolerance of soybean plants by using methyl jasmonate. Physiol. Mol. Bio Plants 2017, 23, 545-556. [CrossRef]

22. Ashry, N.A.; Ghonaim, M.M.; Mohamed, H.I.; Mogazy, A.M. Physiological and molecular genetic studies on two elicitors for improving the tolerance of six Egyptian soybean cultivars to cotton leaf worm. Plant. Physiol. Biochem. 2018, 130, 224-234. [CrossRef]

23. Creelman, R.A.; Mullet, J.E. Jasmonic acid distribution and action in plants: Regulation during development and response to biotic and abiotic stress. Proc. Natl. Acad. Sci. USA 1995, 92, 4114-4119. [CrossRef] [PubMed]

24. Poonam, S.; Kaur, H.; Geetika, S. Effect of jasmonic acid on photosynthetic pigments and stress markers in Cajanus cajan (L.) Millsp. seedlings under copper stress. Am. J. Plant. Sci. 2013, 4, 817. [CrossRef]

25. Rahmani, I.; Ahmadi, N.; Ghanati, F.; Sadeghi, M. Effects of salicylic acid applied pre-or post-transport on post-harvest characteristics and antioxidant enzyme activity of gladiolus cut flower spikes. N. Z. J. Crop. Hortic. Sci. 2015, 43, 294-305. [CrossRef]

26. Liu, Z.; Ding, Y.; Wang, F.; Ye, Y.; Zhu, C. Role of salicylic acid in resistance to cadmium stress in plants. Plant. Cell Rep. 2016, 35, 719-731. [CrossRef] [PubMed]

27. Hafez, E.H.; Seleiman, M.F. Response of barley quality traits, yield and antioxidant enzymes to water-stress and chemical inducers. Intern. J. Plant Prod. 2017, 11, 477-490.

28. Hay, R.; Gilbert, R. Variation in the harvest index of tropical maize: Evaluation of recent evidence from Mexico and Malawi. Ann. Appl. Biol. 2001, 138, 103-109. [CrossRef] 
29. Seleiman, M.F.; Kheir, A.M. Saline soil properties, quality and productivity of wheat grown with bagasse ash and thiourea in different climatic zones. Chemosphere 2018, 193, 538-546. [CrossRef]

30. Pimentel, D.; Patzek, T.W. Ethanol production using corn, switchgrass, and wood; biodiesel production using soybean and sunflower. Nat. Resour. Res. 2005, 14, 65-76. [CrossRef]

31. Bekrić, V.; Radosavljević, M. Savremeni pristupi upotrebe kukuruza. Časopis za Procesnu Tehniku i Energetiku $u$ Poljoprivredi 2008, 12, 93-96.

32. Seleiman, M.F.; Santanen, A.; Stoddard, F.L.; Mäkelä, P. Feedstock quality and growth of bioenergy crops fertilized with sewage sludge. Chemosphere 2012, 89, 1211-1217. [CrossRef] [PubMed]

33. Seleiman, M.F.; Santanen, A.; Jaakkola, S.; Ekholm, P.; Hartikainen, H.; Stoddard, F.L.; Mäkelä, P.S. Biomass yield and quality of bioenergy crops grown with synthetic and organic fertilizers. Biomass Bioenergy 2013, 59, 477-485. [CrossRef]

34. Seleiman, M.F.; Santanen, A.; Kleemola, J.; Stoddard, F.L.; Mäkelä, P.S. Improved sustainability of feedstock production with sludge and interacting mycorrhiza. Chemosphere 2013, 91, 1236-1242. [CrossRef] [PubMed]

35. FAOSTAT. Food and Agriculture Organization of the United Nations Statistics Division. Available online: http://faostat.fao.org/site/567/DesktopDefault.aspx (accessed on 23 February 2020).

36. Ouda, S.; Mohamed, S.G.; Khalil, F.A. Modeling the effect of different stress conditions on maize productivity using yield-stress model. Int. J. Nat. Eng. Sci. 2008, 2, 57-62.

37. Arshad, M.; Lowery, B.; Grossman, B. Physical tests for monitoring soil quality. In Methods for Assessing Soil Quality; Doran, J.W., Jones, A.J., Eds.; Special Publication 49; Soil Science Society of America: Madison, WI, USA, 1997; pp. 123-141.

38. Thomas, G.W. Soil pH and soil acidity. In Methods of Soil Analysis: Part 3; Sparks, D.L., Page, A.L., Helmke, P.A., Loeppert, R.H., Soltanpour, P.N., Tabatabai, M.A., Johnston, C.T., Sumner, M.E., Eds.; John Wiley \& Sons, Ltd.: Hoboken, NJ, USA, 1996; pp. 475-490.

39. Gupta, P.K. Soil, Plant, Water and Fertilizer Analysis; Agrobios: Jodhpur, India, 2009.

40. Vernon, L.; Seely, G. The Chlorophylls; Academic Press: New York, NY, USA, 1966.

41. Lichtenthaler, H.K. Chlorophylls and carotenoids: Pigments of photosynthetic biomembranes. Methods Enzymol. 1987, 350-382.

42. Heath, R.L.; Packer, L. Photoperoxidation in isolated chloroplasts: I. Kinetics and stoichiometry of fatty acid peroxidation. Arch Biochem. Biophys. 1968, 125, 189-198. [CrossRef]

43. Sullivan, C.Y. Selection for drought and heat tolerance in grain sorghum. In Stress Physiology in Crop Plants; Mussell, H., Staples, R.C., Eds.; John Wiley \& Sons: New York, NY, USA, 1979; pp. 263-281.

44. Bates, L.S.; Waldren, R.P.; Teare, I. Rapid determination of free proline for water-stress studies. Plant Soil 1973, 39, 205-207. [CrossRef]

45. Irigoyen, J.; Einerich, D.; Sánchez-Díaz, M. Water stress induced changes in concentrations of proline and total soluble sugars in nodulated alfalfa (Medicago sativa) plants. Physiol. Plant 1992, 84, 55-60. [CrossRef]

46. Griffith, O.W.J. Determination of glutathione and glutathione disulfide using glutathione reductase and 2-vinylpyridine. Anal. Biochem. 1980, 106, 207-212. [CrossRef]

47. Mukherjee, S.; Choudhuri, M. Implications of water stress-induced changes in the levels of endogenous ascorbic acid and hydrogen peroxide in Vigna seedlings. Physiol. Plant 1983, 58, 166-170. [CrossRef]

48. Galicia, L.N.; Rosales, E.; Rojas, A.P.N. Laboratory Protocols: Maize Nutrition Quality and Plant Tissue Analysis Laboratory; CIMMYT: Mexico, DF, Mexico, 2009.

49. Marklund, S.; Marklund, G. Involvement of the superoxide anion radical in the autoxidation of pyrogallol and a convenient assay for superoxide dismutase. Eur. J. Biochem. 1974, 47, 469-474. [CrossRef] [PubMed]

50. Bergmeyer, H.U.; Gawehn, K. Methods of Enzymatic Analysis; Elsevier Academic Press: Cambridge, MA, USA, 1974.

51. Chen, Y.; Cao, X.; Lu, Y.; Wang, X. Effects of rare earth metal ions and their EDTA complexes on antioxidant enzymes of fish liver. Bull. Environ. Contam. Toxicol. 2000, 65, 357-365. [CrossRef] [PubMed]

52. Horwitz, W. Official Methods of Analysis of the Association of Official Agricultural Chemists, 8th ed.; Association of Official Agricultural Chemists: Washington, DC, USA, 1956; p. 347.

53. Jackson, M.L. Soil Chemical Analysis; Prentice Hall of India Pvt. Ltd.: New Delhi, India, 1967; pp. 144-197, 326-338.

54. Page, A.I.; Miller, R.H.; Keeney, D.R. Methods of Soil Analysis. Part 2: Chemical and Microbiological Properties, 2nd ed.; American Society of Agronomy: Madison, WI, USA, 1982. 
55. Barceló, J.; Poschenrieder, C. Plant water relations as affected by heavy metal stress: A review. J. Plant Nutr. 1990, 13, 1-37. [CrossRef]

56. Piotrowska, A.; Bajguz, A.; Godlewska-Żyłkiewicz, B.; Czerpak, R.; Kamińska, M. Jasmonic acid as modulator of lead toxicity in aquatic plant Wolffia arrhiza (Lemnaceae). Environ. Exp. Bot. 2009, 66, 507-513. [CrossRef]

57. Shakirova, F.; Bezrukova, M.; Yuldashev, R.; Fatkhutdinova, R.; Murzabaev, A. Involvement of lectin in the salicylic acid-induced wheat tolerance to cadmium and the role of endogenous ABA in the regulation of its level. Dokl Biol. Sci. 2013, 488, 49-51. [CrossRef]

58. Hayat, S.; Hayat, Q.; Alyemeni, M.N.; Ahmad, A. Proline enhances antioxidative enzyme activity, photosynthesis and yield of Cicer arietinum L. exposed to cadmium stress. Acta Bot. Croat 2013, 72, 323-335. [CrossRef]

59. Alyemeni, M.N.; Hayat, Q.; Wijaya, L.; Hayat, S. Effect of salicylic acid on the growth, photosynthetic efficiency and enzyme activities of leguminous plant under cadmium stress. Not. Bot. Horti Agrobot. Cluj. Napoca 2014, 42, 440-445. [CrossRef]

60. Kwok, D.; Shetty, K. Effects of proline and proline analogs on total phenolic and rosmarinic acid levels in shoot clones of thyme (Thymus vulgaris L.). J. Food Biochem. 1998, 22, 37-51. [CrossRef]

61. Hayat, S.; Hayat, Q. Role of Proline and Salicylic Acid in Overcoming the Stress of Cadmium: Chickpea (Cicer Arietinum); LAP Lambert Academic Publishing: Saarbrücken, Germany, 2011.

62. Ahmad, M.S.A.; Hussain, M.; Ijaz, S.; Alvi, A.K. Photosynthetic performance of two mung bean (Vigna radiata) cultivars under lead and copper stress. Int. J. Agric. Biol. 2008, 10, 167-172.

63. Cenkci, S.; Ciğerci, İ.H.; Yıldız, M.; Özay, C.; Bozdağ, A.; Terzi, H.J.E. Lead contamination reduces chlorophyll biosynthesis and genomic template stability in Brassica rapa L. Environ. Exp. Bot. 2010, 67, 467-473. [CrossRef]

64. Bali, S.; Kaur, P.; Kohli, S.K.; Ohri, P.; Thukral, A.K.; Bhardwaj, R.; Wijaya, L.; Alyemeni, M.N.; Ahmad, P. Jasmonic acid induced changes in physio-biochemical attributes and ascorbate-glutathione pathway in Lycopersicon esculentum under lead stress at different growth stages. Sci. Total Environ. 2018, 645, 1344-1360. [CrossRef] [PubMed]

65. Alamri, S.A.D.; Siddiqui, M.H.; Al-Khaishany, M.Y.; Ali, H.M.; Al-Amri, A.; AlRabiah, H.K. Exogenous application of salicylic acid improves tolerance of wheat plants to lead stress. Adv. Agric. Sci. 2018, 6, 25-35.

66. Zouari, M.; Ahmed, C.B.; Zorrig, W.; Elloumi, N.; Rabhi, M.; Delmail, D.; Rouina, B.B.; Labrousse, P.; Abdallah, F.B. Exogenous proline mediates alleviation of cadmium stress by promoting photosynthetic activity, water status and antioxidative enzymes activities of young date palm (Phoenix dactylifera L.). Ecotoxicol. Environ. Saf. 2016, 128, 100-108. [CrossRef] [PubMed]

67. Deshna, D.; Bafna, A. Effect of lead stress on chlorophyll content, malondialdehyde and peroxidase activity in seedlings of mung bean (Vigna radiata). Int. J. Res. Chem. Environ. 2013, 3, 20-25.

68. Ali, E.; Hussain, N.; Shamsi, I.H.; Jabeen, Z.; Siddiqui, M.H.; Jiang, L.-X. Role of jasmonic acid in improving tolerance of rapeseed (Brassica napus L.) to Cd toxicity. J. Zhejiang Univ. Sci. B 2018, 19, 130-146. [CrossRef]

69. Mehta, S.; Gaur, J. Heavy-metal-induced proline accumulation and its role in ameliorating metal toxicity in Chlorella vulgaris. New Phytol. 1999, 143, 253-259. [CrossRef]

70. Rosa, M.; Prado, C.; Podazza, G.; Interdonato, R.; González, J.A.; Hilal, M.; Prado, F.E. Soluble sugars: Metabolism, sensing and abiotic stress: A complex network in the life of plants. Plant Signal. Behav. 2009, 4, 388-393. [CrossRef]

71. Boguszewska, D.; Zagdańska, B. ROS as signaling molecules and enzymes of plant response to unfavorable environmental conditions. In Oxidative Stress-Molecular Mechanisms and Biological Effects; InTech: Rijeka, Croatia, 2012; pp. 341-362.

72. Hattab, S.; Hattab, S.; Flores-Casseres, M.L.; Boussetta, H.; Doumas, P.; Hernandez, L.E.; Banni, M. Characterisation of lead-induced stress molecular biomarkers in Medicago sativa plants. Environ. Exp. Bot. 2016, 123, 1-12. [CrossRef]

73. Akladious, S.A.; Mohamed, H.I. Ameliorative effects of calcium nitrate and humic acid on the growth, yield component and biochemical attribute of pepper (Capsicum annuum) plants grown under salt stress. Sci. Hortic. 2018, 236, 244-250. [CrossRef]

74. Fontenele, N.M.B.; Otoch, M.; Gomes-Rochette, N.F.; Menezes Sobreira, A.C.; Barreto, A.A.G.C.; Oliveira, F.D.B.; Costa, J.H.; Borges, S.; Nascimento, R.F.; Melo, D.F. Effect of lead on physiological and antioxidant responses in two Vigna unguiculata cultivars differing in Pb-accumulation. Chemosphere 2017, 176, 397-404. [CrossRef] 
75. Maksymiec, W.; Wojcik, M.; Krupa, Z. Variation in oxidative stress and photochemical activity in Arabidopsis thaliana leaves subjected to cadmium and excess copper in the presence or absence of jasmonate and ascorbate. Chemosphere 2007, 66, 421-427. [CrossRef] [PubMed]

76. Kandziora-Ciupa, M.; Ciepał, R.; Nadgórska-Socha, A.; Barczyk, G. Accumulation of heavy metals and antioxidant responses in Pinus sylvestris L. needles in polluted and non-polluted sites. Ecotoxicology 2016, 25, 970-981. [CrossRef] [PubMed]

77. Singh, S.; Sinha, S. Accumulation of metals and its effects in Brassica juncea (L.) Czern.(cv. Rohini) grown on various amendments of tannery waste. Ecotoxicol. Environ. Saf. 2005, 62, 118-127. [CrossRef] [PubMed]

78. Hasanuzzaman, M.; Matin, M.; Fardus, J.; Hasanuzzaman, M.; Hossain, M.; Parvin, K. Foliar application of salicylic acid improves growth and yield attributes by upregulating the antioxidant defense system in Brassica campestris plants grown in lead-amended soils. Acta Agrobot 2019, 72. [CrossRef]

79. Doncheva, S.; Moustakas, M.; Ananieva, K.; Chavdarova, M.; Gesheva, E.; Vassilevska, R.; Mateev, P. Plant response to lead in the presence or absence EDTA in two sunflower genotypes (cultivated H. annuus cv. 1114 and interspecific line H. annuus $\times$ H. argophyllus). Environ. Sci. Pollut. Res. Int. 2013, 20, 823-833. [CrossRef]

80. Bali, S.; Jamwal, V.L.; Kaur, P.; Kohli, S.K.; Ohri, P.; Gandhi, S.G.; Bhardwaj, R.; Al-Huqail, A.A.; Siddiqui, M.H.; Ahmad, P. Role of P-type ATPase metal transporters and plant immunity induced by jasmonic acid against lead $(\mathrm{Pb})$ toxicity in tomato. Ecotoxicol. Environ. Saf. 2019, 174, 283-294. [CrossRef]

81. Hayat, Q.; Hayat, S.; Irfan, M.; Ahmad, A. Effect of exogenous salicylic acid under changing environment: A review. Environ. Exp. Bot. 2010, 68, 14-25. [CrossRef]

82. Jin, X.; Yang, X.; Islam, E.; Liu, D.; Mahmood, Q. Effects of cadmium on ultrastructure and antioxidative defense system in hyperaccumulator and non-hyperaccumulator ecotypes of Sedum alfredii Hance. J. Hazard. Mater. 2008, 156, 387-397. [CrossRef]

83. Phang, C.; Leung, D.W.; Taylor, H.H.; Burritt, D. The protective effect of sodium nitroprusside (SNP) treatment on Arabidopsis thaliana seedlings exposed to toxic level of $\mathrm{Pb}$ is not linked to avoidance of $\mathrm{Pb}$ uptake. Ecotoxicol. Environ. Saf. 2011, 74, 1310-1315. [CrossRef]

84. Metwally, A.; Finkemeier, I.; Georgi, M.; Dietz, K.-J. Salicylic acid alleviates the cadmium toxicity in barley seedlings. J. Plant Physiol. 2003, 132, 272-281. [CrossRef]

85. Ali, Q.; Ashraf, M.; Shahbaz, M.; Humera, H. Ameliorating effect of foliar applied proline on nutrient uptake in water stressed maize (Zea mays L.) plants. Pak. J. Bot. 2008, 40, 211-219.

86. El-Beltagi, H.S.; Mohamed, H.I.; Sofy, M.R. Role of ascorbic acid, glutathione and proline applied as singly or in sequence combination in improving chickpea plant through physiological change and antioxidant defense under different levels of irrigation intervals. Molecules 2020, 25, 1702. [CrossRef] [PubMed] 